Marquette University

e-Publications@Marquette

$8-31-2011$

\title{
Pyrazolyl Methyls Prescribe the Electronic Properties of Iron(II) Tetra(pyrazolyl)lutidine Chloride Complexes
}

Tyler James Morin

Marquette University

Sarath Wanniarachchi

Marquette University, sarath.wanniarachchi@marquette.edu

Chengeto Gwengo

Marquette University

Vitales Makura

Marquette University

Heidi M. Tatlock

Marquette University

See next page for additional authors

Follow this and additional works at: https://epublications.marquette.edu/physics_fac

Part of the Physics Commons

\section{Recommended Citation}

Morin, Tyler James; Wanniarachchi, Sarath; Gwengo, Chengeto; Makura, Vitales; Tatlock, Heidi M.; Lindeman, Sergey; Bennett, Brian; Long, Gary J.; Grandjean, Fernande; and Gardinier, James R., "Pyrazolyl Methyls Prescribe the Electronic Properties of Iron(II) Tetra(pyrazolyl)lutidine Chloride Complexes" (2011). Physics Faculty Research and Publications. 49.

https://epublications.marquette.edu/physics_fac/49 


\section{Authors}

Tyler James Morin, Sarath Wanniarachchi, Chengeto Gwengo, Vitales Makura, Heidi M. Tatlock, Sergey Lindeman, Brian Bennett, Gary J. Long, Fernande Grandjean, and James R. Gardinier 


\title{
Pyrazolyl Methyls Prescribe the Electronic Properties of Iron(II) Tetra(Pyrazolyl)Lutidine Chloride Complexes ${ }^{\dagger}$
}

\author{
Tyler J. Morin \\ Department of Chemistry, Marquette University \\ Milwaukee, WI \\ Sarath Wanniarachchi \\ Department of Chemistry, Marquette University \\ Milwaukee, WI \\ Chengeto Gwengo \\ Department of Chemistry, Marquette University \\ Milwaukee, WI \\ Vitales Makura \\ Department of Chemistry, Marquette University \\ Milwaukee, WI \\ Heidi M. Tatlock \\ Department of Chemistry, Marquette University \\ Milwaukee, WI \\ Sergey V. Lindeman \\ Department of Chemistry, Marquette University \\ Milwaukee, WI \\ Brian Bennett \\ Department of Biophysics, Medical College of Wisconsin \\ Milwaukee, WI
}

Dalton Transactions, Vol. 40, No. 31 (August 2011): pg. 8024-8034. DOI. This article is (c) Royal Society of Chemistry and permission has been granted for this version to appear in e-Publications@Marquette. The Royal Society of Chemistry does not grant permission for this article to be further copied/distributed or hosted elsewhere without the express permission from the Royal Society of Chemistry. 
NOT THE PUBLISHED VERSION; this is the author's final, peer-reviewed manuscript. The published version may be accessed by following the link in the citation at the bottom of the page.

\author{
Gary J. Long \\ Department of Chemistry, Missouri University of Science \& \\ Technology, University of Missouri \\ Rolla, MO \\ Fernande Grandjeand \\ Department of Chemistry, Missouri University of Science \& \\ Technology, University of Missouri \\ Rolla, MO \\ James R. Gardinier \\ Department of Chemistry, Marquette University \\ Milwaukee, WI
}

\begin{abstract}
A series of iron(II) chloride complexes of pentadentate ligands related to $a, a, a^{\prime}, a^{\prime}$-tetra(pyrazolyl)-2,6-lutidine, pzlut, has been prepared to evaluate whether pyrazolyl substitution has any systematic impact on the electronic properties of the complexes. For this purpose, the new tetrakis(3,4,5-trimethylpyrazolyl)lutidine ligand, pz** ${ }_{4}$ lut, was prepared via a $\mathrm{CoCl}_{2}$-catalyzed rearrangement reaction. The equimolar combination of ligand and $\mathrm{FeCl}_{2}$ in methanol gives the appropriate $1: 1$ complexes $\left[\mathrm{FeCl}\left(\mathrm{pZ}^{\mathrm{R}}{ }_{4} \mathrm{lut}\right)\right] \mathrm{Cl}$ that are each isolated in the solid state as a hygroscopic solvate. In solution, the iron(II) complexes have been fully characterized by several spectroscopic methods and cyclic voltammetry. In the solid state, the complexes have been characterized by X-ray diffraction, and, in some cases, by Mössbauer spectroscopy. The Mössbauer studies show that the complexes remain high spin to $4 \mathrm{~K}$ and exclude spin-state changes as the cause of the surprising solid-state thermochromic properties of the complexes. Non-intuitive results of spectroscopic and structural studies showed that methyl substitution at the 3- and 5positions of the pyrazolyl rings reduces the ligand field strength through steric effects whereas methyl substitution at the 4-position of the pyrazolyl rings increases the ligand field strength through inductive effects.
\end{abstract}

\title{
Introduction
}

The prevalence of the $\mathrm{FeN}_{5} \mathrm{X}$ coordination manifold in biological systems has served as an inspiration for the design of man-made iron complexes with nitrogenous pentadentate ligands. ${ }^{1}$ Investigations into the coordination chemistry of such model compounds have greatly

Dalton Transactions, Vol. 40, No. 31 (August 2011): pg. 8024-8034. DOI. This article is (c) Royal Society of Chemistry and permission has been granted for this version to appear in e-Publications@Marquette. The Royal Society of Chemistry does not grant permission for this article to be further copied/distributed or hosted elsewhere without the express permission from the Royal Society of Chemistry. 
improved our understanding of natural metalloenzymes and have also lead to important new chemical discoveries that traverse research areas from bioinorganic to materials chemistry. Prominent among these pentadentate ligand systems is the PY5-R class, on the left of Fig. 1. Iron PY5-R complexes have found utility in a variety of biological and non- biological inorganic studies. $\underline{2-4}$

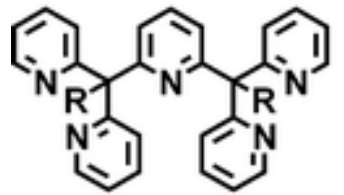

PY5-R

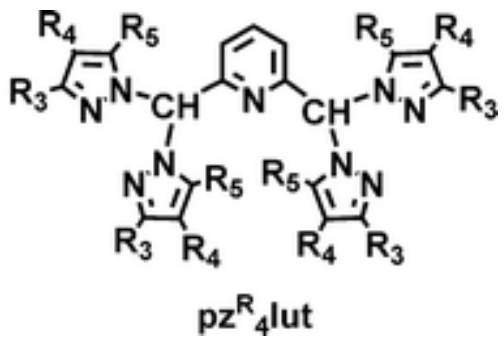

Fig. 1 Two related classes of pentadentate ligands.

We recently developed a new class of potentially pentadentate ligands based on variants of tetra(pyrazolyl)lutidine, $\mathrm{pz}^{\mathrm{R}}{ }_{4}$ lut, shown in the right of Fig. 1.5,6 The ready availability of the nearly endless pyrazole derivatives and the simple synthetic routes to the $\mathrm{pz}^{\mathrm{R}}{ }_{4}$ lut ligands presage numerous avenues for study in coordination chemistry. Our initial communication described a survey of some first row transition metal(II) chloride complexes of pzulut, which showed that in the solid state nickel(II) was the best fit for the ligand pocket. $\underline{5}$ It was subsequently found in silver(I) chemistry that very different coordination modes and solution behaviour were obtained by making simple changes of the pyrazolyl substituents. $\frac{6}{}$ Given our ultimate desire to explore iron chemistry and the surprising results found for silver chemistry, we decided that it would be prudent to investigate whether substitution of hydrogen by methyls on pyrazolyl groups in $\mathrm{pz}^{\mathrm{R}}$ lut ligands would have any impact on the structures or electronic properties of their iron complexes. For this purpose, we first chose to examine iron(II) chloride complexes owing to their potential use as reagents for further chemistry. 
NOT THE PUBLISHED VERSION; this is the author's final, peer-reviewed manuscript. The published version may be accessed by following the link in the citation at the bottom of the page.

\section{Results and Discussion}

\section{Preparation}

The $\mathrm{pz}^{* *}{ }_{4}$ lut ligand used in this work is new and has been prepared in a manner analogous to that previously described in the literature for the other three $\mathrm{pz}^{\mathrm{R}}{ }_{4}$ lut ligands,$\underline{5,6}$ as summarized in the experimental section and in the first portion of Scheme 1 . One should note that the $\mathrm{CoCl}_{2}$-catalyzed rearrangement reaction? ${ }^{7}$ between 2,6 pyridinedicarboxaldehyde -8 (PDCA) and $\mathrm{S}(\mathrm{O})\left(\mathrm{pz}^{* *}\right)_{2}$ (prepared in situ) was found to require an excess of the latter reagent for good yields of the $\mathrm{pz}^{* *}{ }_{4}$ lut ligand. Much lower yields (ca. $15-30 \%$ based on PDCA) of the $\mathrm{pz}^{* *}{ }_{4}$ lut ligand are obtained if only two equivalents of $\mathrm{S}(\mathrm{O})\left(\mathrm{pz}^{* *}\right)_{2}$ are used. The excess $\mathrm{H}\left(\mathrm{pz}^{* *}\right)$ used in the former preparative reaction can be recovered from the product mixture after synthesis by flushing the column with methanol and subliming the residue, a recovery which is fortuitous because this starting material is not commercially available.

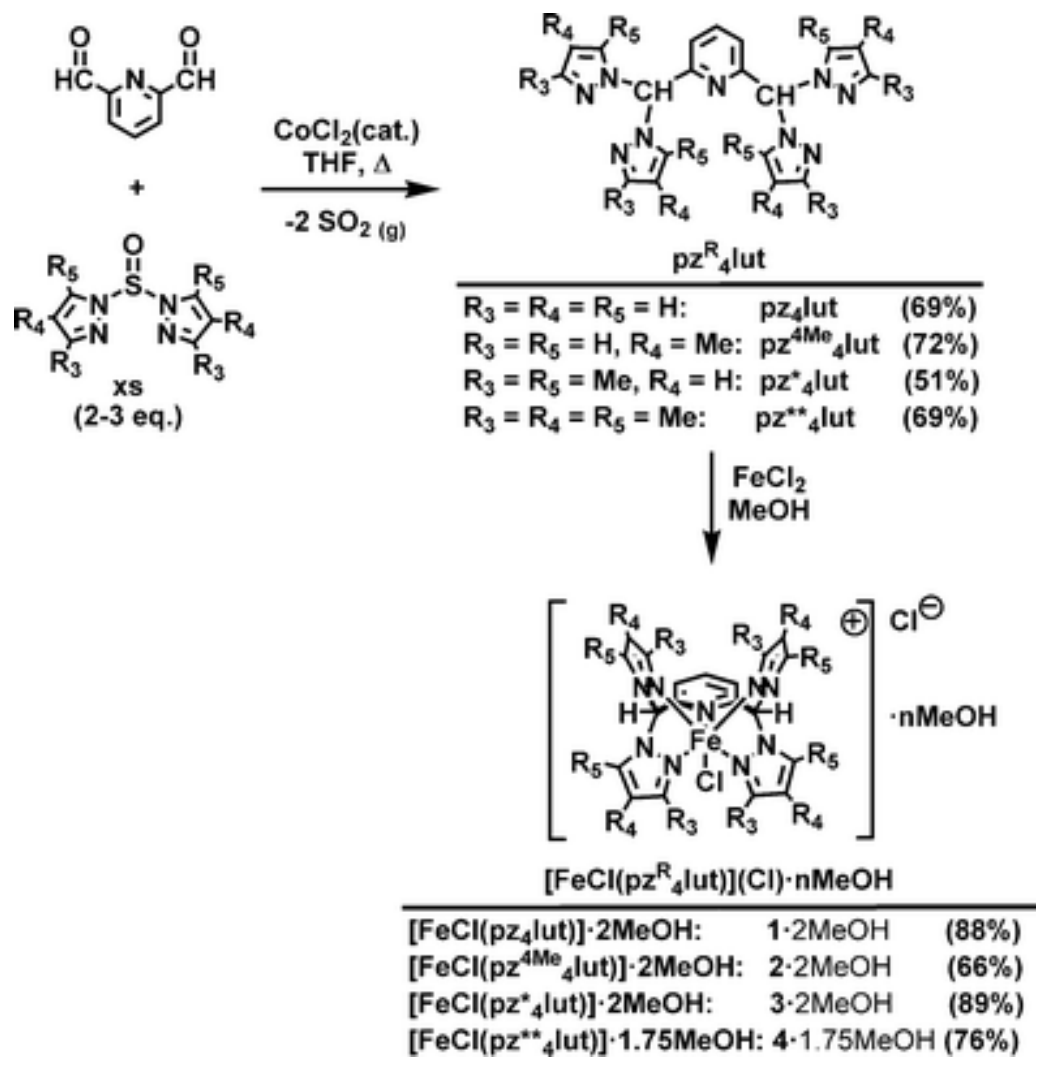

Scheme 1 Preparation of the $\mathrm{pz}^{\mathrm{R}}{ }_{4}$ lut ligands and their $\mathrm{FeCl}_{2}$ complexes.

Dalton Transactions, Vol. 40, No. 31 (August 2011): pg. 8024-8034. DOI. This article is (c) Royal Society of Chemistry and permission has been granted for this version to appear in e-Publications@ Marquette. The Royal Society of Chemistry does not grant permission for this article to be further copied/distributed or hosted elsewhere without the express permission from the Royal Society of Chemistry. 
The reactions between methanol solutions of anhydrous $\mathrm{FeCl}_{2}$ and the various $\mathrm{pz}^{\mathrm{R}}{ }_{4}$ lut ligands result in the precipitation of the microcrystalline iron(II) complexes $\left[\mathrm{FeCl}\left(\mathrm{pz}_{4} \mathrm{lut}\right)\right] \mathrm{Cl} \cdot 2 \mathrm{MeOH}$ (1.2MeOH), $\left[\mathrm{FeCl}\left(\mathrm{pz}^{4 \mathrm{Me}}{ }_{4}\right.\right.$ lut $\left.)\right] \mathrm{Cl} \cdot \mathrm{MeOH}(\mathbf{2} \cdot \mathrm{MeOH})$, $\left[\mathrm{FeCl}\left(\mathrm{pz} *_{4}\right.\right.$ lut $\left.)\right] \mathrm{Cl} \cdot 2 \mathrm{MeOH}(3 \cdot 2 \mathrm{MeOH})$, and $\left[\mathrm{FeCl}\left(\mathrm{pz} * *_{4}\right.\right.$ lut $\left.)\right] \mathrm{Cl} \cdot 1.75 \mathrm{MeOH}$ $(4 \cdot 1.75 \mathrm{MeOH})$ in high yield. The complexes exhibit relatively low solubilities in methanol of ca. $0.004,0.01,0.02$, and $0.03 \mathrm{M}$ for 1-4, respectively, and are practically insoluble in most other organic solvents and in water. The complexes are hygroscopic and form trihydrates, $\left[\mathrm{Fe}(\mathrm{Cl})\left(\mathrm{pz}^{\mathrm{R}}{ }_{4} \mathrm{lut}\right)\right](\mathrm{Cl}) \cdot 3 \mathrm{H}_{2} \mathrm{O}$ (combustion analyses), when left unprotected under ambient conditions for a few weeks. For this reason, electrochemical and spectroscopic measurements were made on samples freshly crystallized from methanol and vacuum dried. Room temperature magnetic susceptibility measurements indicate that complexes 1-4 are paramagnetic in solution with $\mu_{\text {eff }}>5 \mu_{\mathrm{B}}$ that are typical for high-spin iron(II) ( $\mathrm{S}=2$ ) with unquenched orbital angular momentum. Complexes $\mathbf{1}$ and $\mathbf{2}$ are also noticeably thermochromic in the solid state, at low temperature $(77 \mathrm{~K})$ the complexes are pale yellow and gradually become orange upon warming to room temperature and above. Comparisons of high and low temperature single crystal $\mathrm{X}$-ray diffraction data for $1 \cdot \mathrm{CH}_{2} \mathrm{Cl}_{2}$ and $4 \cdot 1.75 \mathrm{MeOH}$ show comparable but insignificant variations in bond distances with temperature, see Supporting Information. Therefore, the solid-state thermochromic behaviour of $\mathbf{1}$ and $\mathbf{2}$ is attributed to changes in the intensity and possibly the energy of charge-transfer electronic transitions (vide infra) rather than to changes in the electronic spin state of the iron(II).

\section{Solid State Structures}

Single crystals suitable for $\underline{X}$-ray diffraction have been obtained for each $\left[\mathrm{FeCl}\left(\mathrm{pz}^{\mathrm{R}}{ }_{4} \mathrm{lut}\right)\right](\mathrm{Cl})$ complex either by cooling supersaturated methanol solutions to give $1 \cdot 2 \mathrm{MeOH}, 3 \cdot 2 \mathrm{MeOH}, 4 \cdot 1.75 \mathrm{MeOH}$, or by diffusion of diethyl ether into methanol solutions of $\mathbf{2}$ to give $\mathbf{2} \cdot \mathrm{MeOH} \cdot 0.35 \mathrm{Et}_{2} \mathrm{O}$. Selected views of the structures of various $\left[\mathrm{FeCl}\left(\mathrm{pz}_{4}{ }_{4} \mathrm{lut}\right)\right]^{+}$cations are found in Fig. 2, 3, and 4. Further depictions of all structures can be found in the Supporting Information. Selected bond distances and angles for the complexes are given in Table 1 . The ligand in each complex is pentadentate and gives rise to a

Dalton Transactions, Vol. 40, No. 31 (August 2011): pg. 8024-8034. DOI. This article is (c) Royal Society of Chemistry and permission has been granted for this version to appear in e-Publications@Marquette. The Royal Society of Chemistry does not grant permission for this article to be further copied/distributed or hosted elsewhere without the express permission from the Royal Society of Chemistry. 
$\mathrm{FeN}_{5} \mathrm{Cl}$ coordination environment. The iron-ligand bond distances in 14 are indicative of high-spin iron(II). For instance, the average Fe$\mathrm{N}$ (pyrazolyl), Fe- $\mathrm{N}_{\mathrm{pz}}$, bond distances in the complexes 1-4 are greater than $2.10 \AA$ (Table 1 ), distinctive of high-spin iron(II) in a wide range of complexes with pyrazolyl-containing ligands. In contrast, low-spin iron(II) derivatives have average $\mathrm{Fe}-\mathrm{N}_{\mathrm{pz}}$ bond distances of ca. 1.98

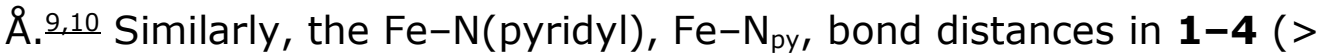
$2.2 \AA$ ) are typical of high-spin iron(II) exemplified by the related PY5 complexes. 11 The $\mathrm{Fe}-\mathrm{Cl}$ bond distance is rather insensitive to the ligand variation across the series $\mathbf{1 - 4}$ and remains in the narrow range of 2.3137(6) to 2.3512(9) $\AA$. Interestingly, a comparison of the structures of the four complexes 1-4 (Fig. 3) and of the associated metric parameters (Table 1 ) reveals that these complexes can be divided into two subsets based on whether or not methyl groups occupy the 3-positions of the pyrazolyls that are proximal to the ironbound chloride. Complexes $\mathbf{3}$ and 4, with 3-methyl substituents, each have longer average $\mathrm{Fe}-\mathrm{N}_{\mathrm{pz}}$ bonds of 2.280(2) $\AA$ and relatively large average FeN-NC methine torsion angles of $6.6(2)^{\circ}$ for 3 and $13.1(3)^{\circ}$ for 4, values that are indicative of greater pyrazolyl ring twisting as compared with the other two derivatives with hydrogen at the 3position of the pyrazolyls (Fe-N $\mathrm{N}_{\mathrm{pz}} 2.197(1) \AA$, FeN-NCmethine $1.3(3)^{\circ}$ for 1 and $\mathrm{Fe}-\mathrm{N}_{\mathrm{pz}} 2.177(2) \AA, \mathrm{FeN}-\mathrm{NC}_{\text {methine }} 4.6(3)^{\circ}$ for 2). The space-filling structural representations in Fig. 4 reveal that the dichotomy in the two types of structures may be due in part to two types of steric interactions; those between 3-methyl substituents, see the red arrows in Fig. 4, and those interactions between 3-methyl pyrazolyl substituents and the axial chloride group, see the yellow arrows in Fig. 4. The increase in both the Fe- $\mathrm{N}_{\mathrm{pz}}$ bond lengths and in the twisting of the ligand pyrazolyl rings for $\mathbf{3}$ and $\mathbf{4}$ relative to $\mathbf{1}$ and $\mathbf{2}$ presumably alleviates unfavourable steric interactions in a similar, but less dramatic, manner than is found in related iron(II) tris(pyrazolyl)borate or tris(pyrazolyl)methane complexes in which the spin state changes depend on whether or not 3-methyl pyrazolyl substituents are present. $\underline{9}$

Dalton Transactions, Vol. 40, No. 31 (August 2011): pg. 8024-8034. DOI. This article is (c) Royal Society of Chemistry and permission has been granted for this version to appear in e-Publications@Marquette. The Royal Society of Chemistry does not grant permission for this article to be further copied/distributed or hosted elsewhere without the express permission from the Royal Society of Chemistry. 
Table 1 Selected interatomic bond distances $(\AA)$, bond angles $\left({ }^{\circ}\right)$, and bond torsions $\left({ }^{\circ}\right)$ in $\mathbf{1 - 4}$

\begin{tabular}{|c|c|c|c|c|c|c|}
\hline Distances ( $\AA$ ) & 1.MeOH & 1.2MeOH & $2 \cdot \mathrm{MeOH} \cdot 0.35 \mathrm{Et}_{2} \mathrm{O}$ & 3.2MeOH & 4.1.75MeC & OH \\
\hline $\mathrm{Fe} 1-\mathrm{Cl}$ & $2.3137(6)$ & $2.3512(9)$ & $2.3230(6)$ & $2.3282(9)$ & $2.3332(7)$ & $2.3303(7)$ \\
\hline Fe1-N1 & $2.243(1)$ & $2.258(3)$ & $2.268(2)$ & $2.218(3)$ & $2.207(2)$ & $2.211(2)$ \\
\hline Fe1-N11 & $2.188(1)$ & $2.175(2)$ & $2.169(2)$ & $2.245(2)$ & $2.322(2)$ & $2.286(2)$ \\
\hline Fe1-N21 & $2.188(1)$ & $2.175(2)$ & $2.185(2)$ & $2.245(2)$ & $2.307(2)$ & $2.270(2)$ \\
\hline Fe1-N31 & $2.205(1)$ & $2.177(2)$ & $2.182(2)$ & $2.317(2)$ & $2.2612)$ & $2.247(2)$ \\
\hline Fe1-N41 & $2.205(1)$ & $2.177(2)$ & $2.175(2)$ & $2.317(2)$ & $2.257(2)$ & $2.289(2)$ \\
\hline Avg Axial & $2.279(1)$ & $2.305(2)$ & $2.295(2)$ & $2.273(2)$ & $2.276(1)$ & $2.271(1)$ \\
\hline Avg Equatorial & $2.197(1)$ & $2.176(2)$ & $2.177(2)$ & $2.281(2)$ & $2.287(2)$ & $2.273(2)$ \\
\hline Avg All & $2.224(1)$ & $2.219(2)$ & $2.216(2)$ & $2.278(2)$ & $2.281(2)$ & $2.272(2)$ \\
\hline \multicolumn{7}{|l|}{ Angles $\left({ }^{\circ}\right)$} \\
\hline $\mathrm{N} 1-\mathrm{Fe}-\mathrm{Cl}$ & $176.29(4)$ & 177.81(10) & $177.98(5)$ & $176.82(7)$ & 178.91(5) & $178.44(5)$ \\
\hline N11-Fe1-N21 & $81.90(4)$ & $82.15(7)$ & $83.90(7)$ & $82.81(9)$ & $77.93(7)$ & $78.22(7)$ \\
\hline N31-Fe1-N41 & $81.90(4)$ & $82.15(7)$ & $83.99(7)$ & $74.98(9)$ & $79.76(7)$ & $78.59(7)$ \\
\hline N11-Fe1-N41 & $92.37(6)$ & $96.63(13)$ & $92.75(7)$ & $99.18(6)$ & $98.21(7)$ & $101.45(7)$ \\
\hline N21-Fe1-N31 & $98.56(6)$ & $93.58(13)$ & $92.89(7)$ & $99.18(6)$ & $100.52(7)$ & $99.16(8)$ \\
\hline N11-Fe1-N31 & $162.34(4)$ & $162.18(7)$ & $161.38(7)$ & $164.69(7)$ & $167.83(8)$ & $160.32(8)$ \\
\hline $\mathrm{N} 21-\mathrm{Fe}-\mathrm{N} 41$ & $162.34(4)$ & $162.18(7)$ & 159.99(7) & $164.69(7)$ & $163.22(8)$ & $172.50(8)$ \\
\hline \multicolumn{7}{|l|}{ Torsions $\left({ }^{\circ}\right)$} \\
\hline Fe1N11-N12C1 & $0.62(14)$ & $0.0(3)$ & $3.4(3)$ & $2.5(2)$ & $-22.9(3)$ & $8.2(3)$ \\
\hline Fe1N21-N22C1 & $-2.96(13)$ & $1.7(3)$ & $-6.2(2)$ & $-2.5(2)$ & $-16.0(3)$ & $19.0(3)$ \\
\hline Fe1N31-N32C7 & $2.96(13)$ & $-1.7(3)$ & $4.1(2)$ & $-10.7(2)$ & $1.3(3)$ & $8.1(3)$ \\
\hline Fe1N41-N42C7 & $-0.62(14)$ & $-0.0(3)$ & $-4.7(3)$ & $10.7(2)$ & $10.0(3)$ & $19.1(2)$ \\
\hline Fe1N1-C2C1 & $-1.78(17)$ & $1.6(4)$ & $0.4(3)$ & 0.0 & $-10.3(3)$ & $3.7(3)$ \\
\hline Fe1N1-C6C7 & $1.78(17)$ & $-1.6(4)$ & $0.1(2)$ & 0.0 & $8.4(4)$ & $-2.2(3)$ \\
\hline
\end{tabular}

Dalton Transactions, Vol. 40, No. 31 (August 2011): pg. 8024-8034. DOI. This article is @ Royal Society of Chemistry and permission has been granted for this version to appear in e-Publications@Marquette. The Royal Society of Chemistry does not grant permission for this article to be further copied/distributed or hosted elsewhere without the express permission from the Royal Society of Chemistry. 
NOT THE PUBLISHED VERSION; this is the author's final, peer-reviewed manuscript. The published version may be accessed by following the link in the citation at the bottom of the page.

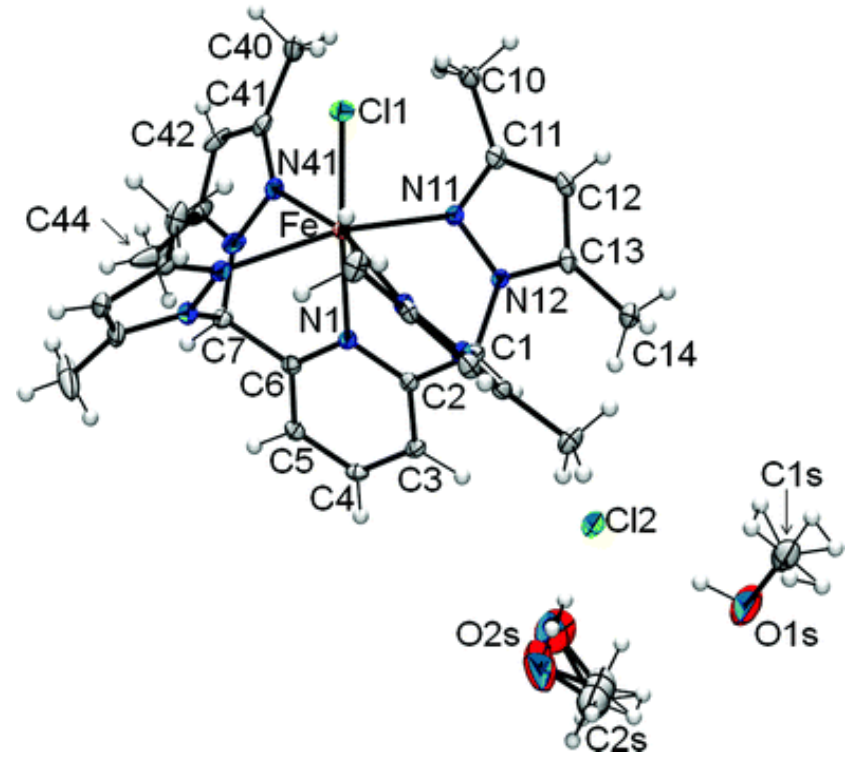

Fig. 2 Structure of $\left[\mathrm{FeCl}\left(\mathrm{pz}_{4}{ }_{4} \mathrm{lut}\right)\right] \mathrm{Cl} \cdot 2 \mathrm{MeOH}(\mathbf{3} \cdot 2 \mathrm{MeOH})$ shown with thermal ellipsoids at the $50 \%$ probability level.

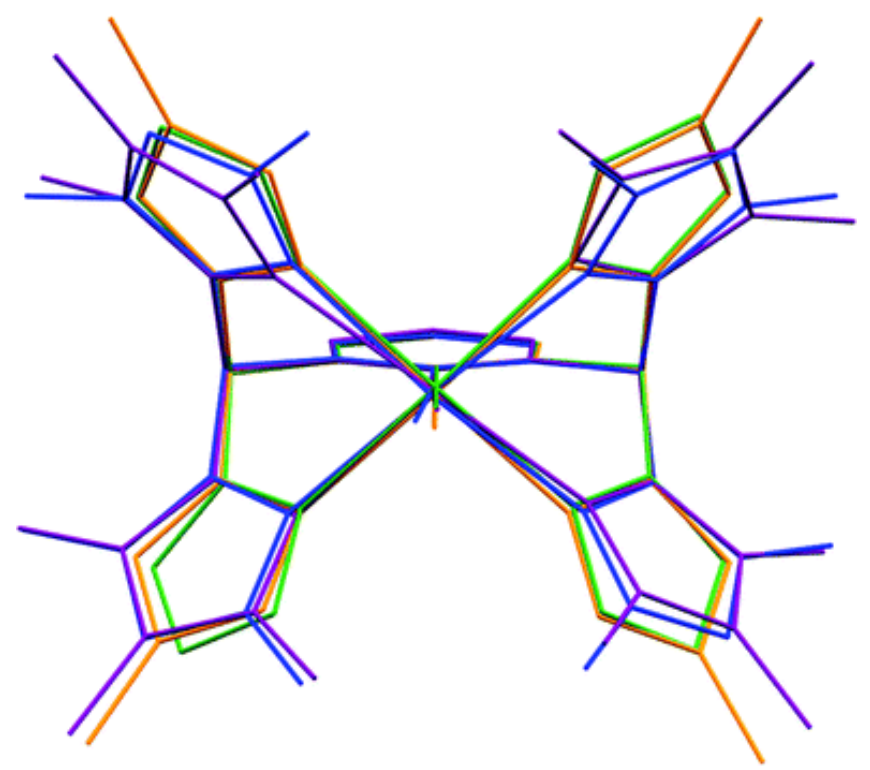

Fig. $\mathbf{3}$ Overlay of all cation structures in $\mathbf{1}$ (green), $\mathbf{2}$ (orange), $\mathbf{3}$ (blue) and 4 (violet).

Dalton Transactions, Vol. 40, No. 31 (August 2011): pg. 8024-8034. DOI. This article is @ Royal Society of Chemistry and permission has been granted for this version to appear in e-Publications@Marquette. The Royal Society of Chemistry does not grant permission for this article to be further copied/distributed or hosted elsewhere without the express permission from the Royal Society of Chemistry. 

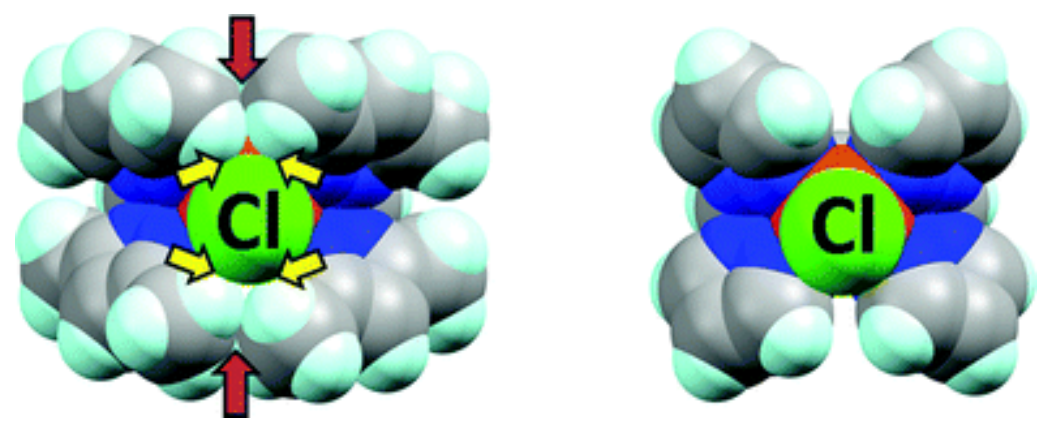

Fig. 4 Space-filling representations for cations in $\mathbf{3}$ (left) and $\mathbf{1}$ (right); areas with potential steric interactions are highlighted by arrows.

The solids obtained directly from the preparative reactions of 14 are microcrystalline as determined by powder X-ray diffraction measurements. In the cases of $\mathbf{1}$ and $\mathbf{3}$ where more than one type of crystal were obtained, comparison of the powder patterns with those predicted from the single crystal X-ray diffraction studies provide additional evidence (apart from combustion analyses) that the bulk samples are di-methanol solvates as exemplified for $\mathbf{1}$ in Fig. 5 (see the supporting information \pm for other examples). For $\mathbf{4}$, the experimental powder X-ray diffraction patterns of the microcrystalline precipitates match those calculated from the single crystal structural data indicating that the single crystals appear to be representative of the bulk samples, see the supporting information. \pm

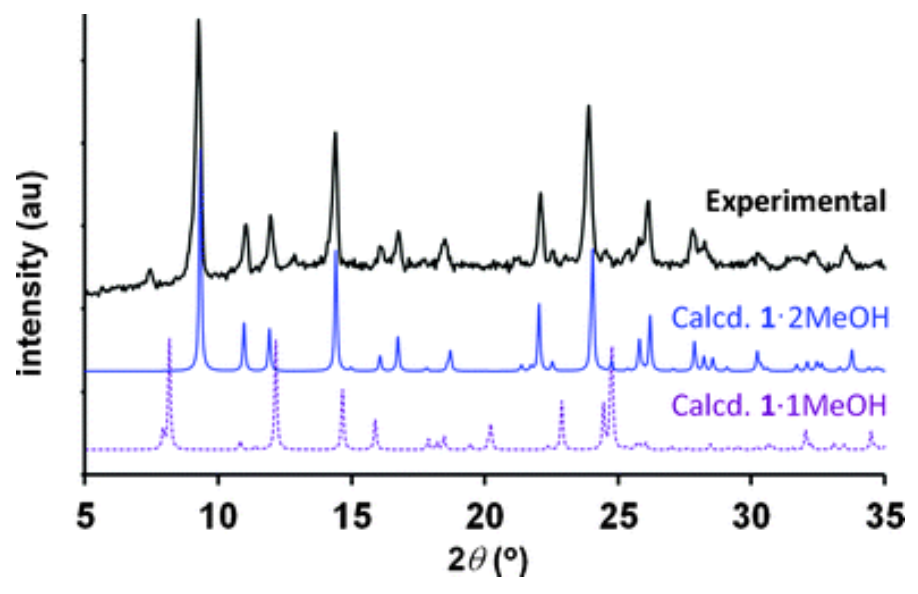

Fig. 5 Comparison of the X-ray diffraction patterns from the powder obtained directly from the preparative reaction of $\mathbf{1}$ (black, top) and those calculated using single-crystal X-ray diffraction data for the di- (middle) and mono- (violet, bottom) methanol solvates. permission has been granted for this version to appear in e-Publications@ Marquette. The Royal Society of Chemistry does not grant permission for this article to be further copied/distributed or hosted elsewhere without the express permission from the Royal Society of Chemistry. 


\section{Mössbauer Spectroscopy}

The iron-57 Mössbauer spectra of two representative complexes, $[\mathrm{FeCl}(\mathrm{pz}$ lut $)] \mathrm{Cl} \cdot \mathrm{CH}_{2} \mathrm{Cl}_{2}, \mathbf{1} \cdot \mathrm{CH}_{2} \mathrm{Cl}_{2}$, and $\left[\mathrm{FeCl}\left(\mathrm{pz}_{4}{ }_{4} \mathrm{lut}\right)\right] \mathrm{Cl} \cdot 2 \mathrm{MeOH}, 3 \cdot 2 \mathrm{MeOH}$, have been measured as a function of temperature and representative spectra are shown in Fig. 6 . The remaining spectra are virtually identical to those shown in this figure; the parameters corresponding to the spectral fits are given in Table 2. The temperature dependence of the isomer shifts, $\delta$, quadrupole splittings, $\Delta \mathrm{E}_{\mathrm{Q}}$, and spectral absorption areas are shown in Fig. 7.

Table 2 Mössbauer spectral parameters

\begin{tabular}{|c|c|c|c|c|c|c|}
\hline Complex & $T / K$ & $\begin{array}{l}\delta, \mathrm{mm} \\
\mathrm{s}^{-1 \underline{a}}\end{array}$ & $\begin{array}{l}<\Delta E_{Q}> \\
\mathrm{mm} \mathrm{s}^{-1}\end{array}$ & $\begin{array}{l}\Gamma_{,}, \mathrm{mm} \\
\mathrm{s}^{-1}\end{array}$ & $\begin{array}{l}\sigma, \mathbf{m m} \\
\mathbf{s}^{-1}\end{array}$ & $\begin{array}{l}\text { Area, (\%ع) } \\
\left(\mathrm{mm} \mathrm{s}^{-1}\right)\end{array}$ \\
\hline \multicolumn{7}{|c|}{$\begin{array}{l}\text { a The isomer shifts are given relative } \\
\text { to } 295 \mathrm{~K} \mathrm{a} \text {-iron powder. b } \\
\text { Constrained to the value given. }\end{array}$} \\
\hline \multirow[t]{4}{*}{ 1. $\mathrm{CH}_{2} \mathrm{Cl}_{2}$} & 295 & 1.047 & 3.04 & 0.26 & - & 2.198 \\
\hline & 225 & 1.090 & 3.14 & 0.26 & - & 3.523 \\
\hline & 155 & 1.126 & 3.22 & 0.26 & - & 5.211 \\
\hline & 85 & 1.157 & 3.28 & 0.26 & - & 6.944 \\
\hline \multirow[t]{9}{*}{ 3. $\mathrm{MeOH}$} & 295 & 1.079 & 1.29 & $0.24^{b}$ & 0.096 & 1.674 \\
\hline & 225 & 1.126 & 1.27 & $0.24^{b}$ & 0.130 & 2.549 \\
\hline & 155 & 1.171 & 1.48 & $0.24^{b}$ & 0.155 & 4.162 \\
\hline & 120 & 1.190 & 1.76 & $0.24^{\underline{b}}$ & 0.202 & 5.226 \\
\hline & 85 & 1.209 & 2.01 & $0.24^{b}$ & 0.219 & 6.051 \\
\hline & 60 & 1.223 & 2.15 & $0.24^{b}$ & 0.181 & 6.947 \\
\hline & 40 & 1.230 & 2.16 & $0.24^{\underline{b}}$ & 0.172 & 7.594 \\
\hline & 20 & 1.231 & 2.17 & $0.24^{\underline{b}}$ & 0.166 & 7.988 \\
\hline & 4.2 & 1.231 & 2.17 & $0.24^{\underline{b}}$ & 0.169 & 8.133 \\
\hline
\end{tabular}

Dalton Transactions, Vol. 40, No. 31 (August 2011): pg. 8024-8034. DOI. This article is (c) Royal Society of Chemistry and permission has been granted for this version to appear in e-Publications@Marquette. The Royal Society of Chemistry does not grant permission for this article to be further copied/distributed or hosted elsewhere without the express permission from the Royal Society of Chemistry. 
NOT THE PUBLISHED VERSION; this is the author's final, peer-reviewed manuscript. The published version may be accessed by following the link in the citation at the bottom of the page.
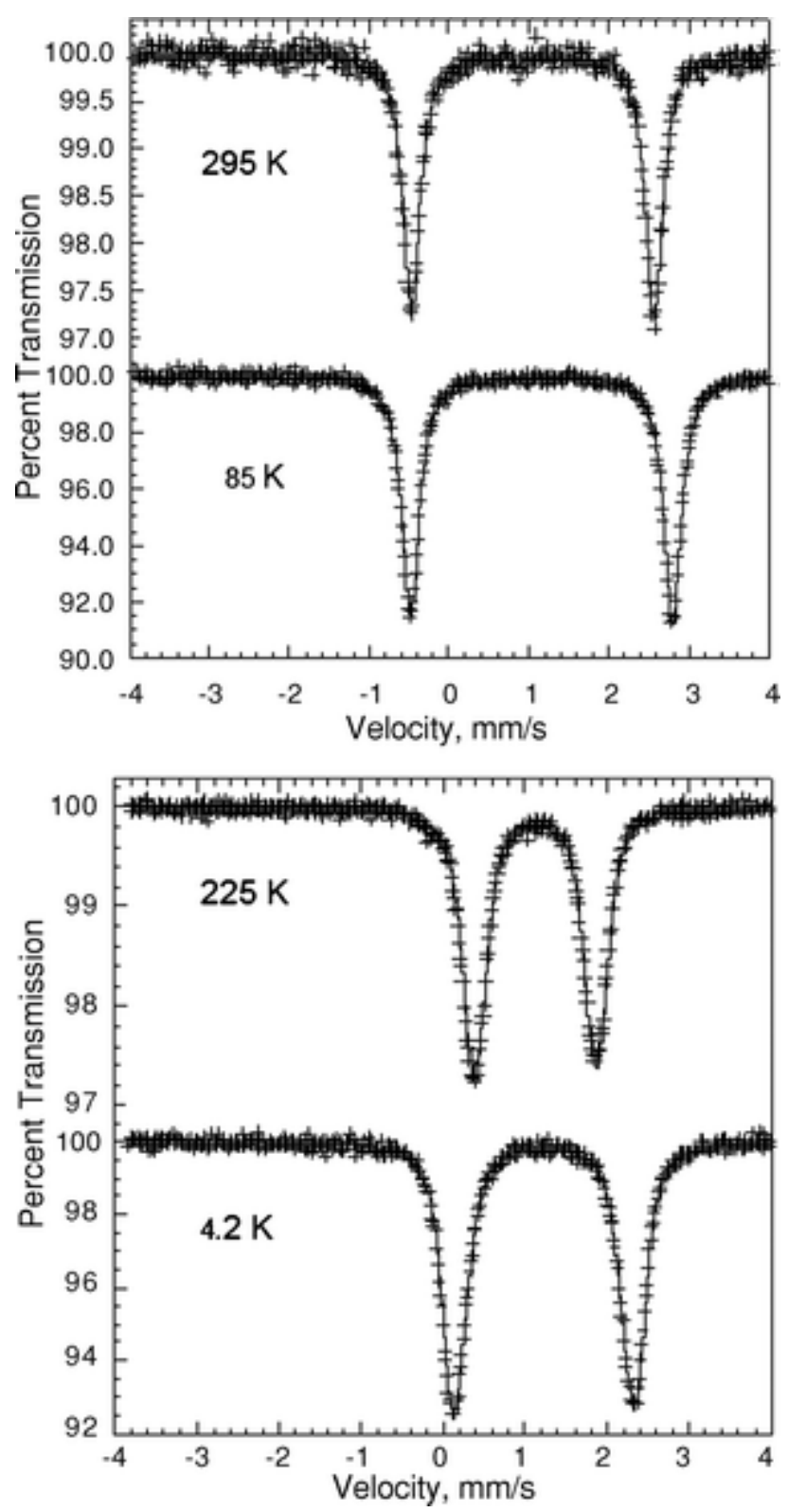

Fig. 6 Mössbauer spectra of $[\mathrm{FeCl}($ pzzlut $)] \mathrm{Cl} \cdot \mathrm{CH}_{2} \mathrm{Cl}_{2}, \mathbf{1} \cdot \mathrm{CH}_{2} \mathrm{Cl}_{2}$, upper, and $\left[\mathrm{FeCl}\left(\mathrm{pz}_{4}\right.\right.$ lut $\left.)\right] \mathrm{Cl} \cdot 2 \mathrm{MeOH}, 3 \cdot 2 \mathrm{MeOH}$, lower, obtained at the indicated temperatures.

Dalton Transactions, Vol. 40, No. 31 (August 2011): pg. 8024-8034. DOI. This article is (C) Royal Society of Chemistry and permission has been granted for this version to appear in e-Publications@Marquette. The Royal Society of Chemistry does not grant permission for this article to be further copied/distributed or hosted elsewhere without the express permission from the Royal Society of Chemistry. 
NOT THE PUBLISHED VERSION; this is the author's final, peer-reviewed manuscript. The published version may be accessed by following the link in the citation at the bottom of the page.
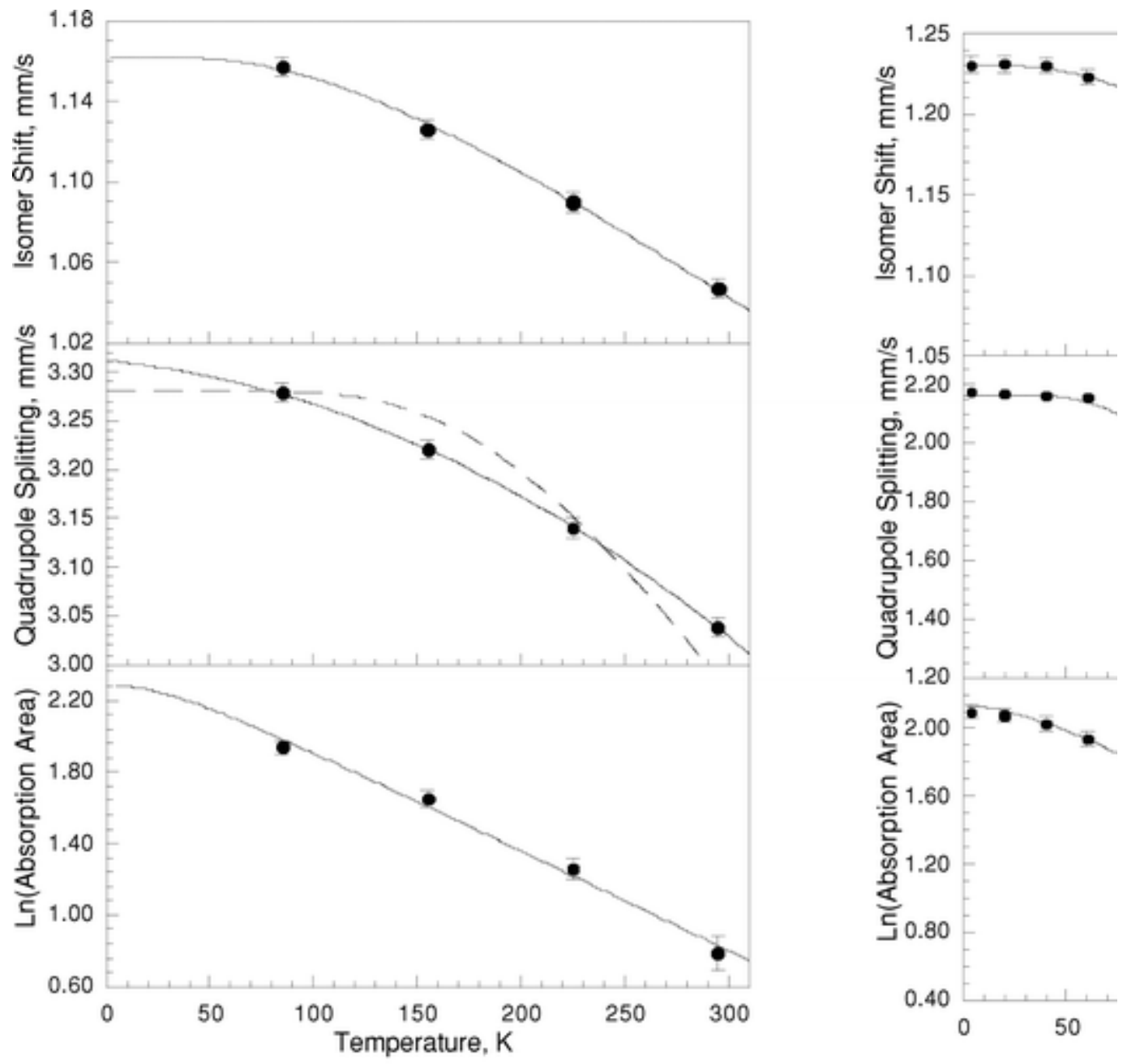

Fig. 7 The temperature dependence of the isomer shifts, upper, the quadrupole splittings, center, and the logarithm of the spectral absorption areas, lower, observed for $\mathbf{1} \cdot \mathrm{CH}_{2} \mathrm{Cl}_{2}$, left, and $\mathbf{3} \cdot 2 \mathrm{MeOH}$, right. The temperature dependence of the isomer shifts and the logarithm of the spectral absorption areas have been fit with the Debye model for a solid; the fits of the quadrupole splittings are discussed in the text. In the absence of error bars the errors are the size of the data points.

The Mössbauer spectra of $\mathbf{1} \cdot \mathrm{CH}_{2} \mathrm{Cl}_{2}$ have been fit with a symmetric quadrupole doublet that is fully consistent $\frac{12}{2}$ with the presence of a single pseudooctahedral high-spin iron(II) site, $\underline{5}$ also see Fig. $\mathrm{S} 1$ in the supporting information. \pm The narrow line width, $\Gamma$, of $0.26 \mathrm{~mm} \mathrm{~s}^{-1}$ is indicative of a single crystallographic iron(II) site as is observed $\underline{5}$ in $\mathbf{1} \cdot \mathrm{CH}_{2} \mathrm{Cl}_{2}$ and it is only slightly larger than the line width 
of $0.24 \mathrm{~mm} \mathrm{~s}^{-1}$ observed for an absorber containing $10 \mathrm{mg} \mathrm{cm}^{-2}$ of $\mathrm{FeSO}_{4} \cdot 5 \mathrm{H}_{2} \mathrm{O}$ measured under the same experimental conditions.

In contrast, the Mössbauer spectra of $3 \cdot 2 \mathrm{MeOH}$, which are also consistent $\underline{12}$ with the presence of pseudooctahedral high-spin iron(II), exhibit a larger line width of ca. $0.36 \mathrm{~mm} \mathrm{~s}^{-1}$ when fit with a single quadrupole doublet; the corresponding fits are rather poor. Because the X-ray structure of $3 \cdot 2 \mathrm{MeOH}$ exhibits only one crystallographic iron(II) site, we believe that the broadened spectral absorption results from a partial loss of some of the $\mathrm{MeOH}$ molecules of solvation and/or their replacement with water of solvation to yield slight variations in the local environment about the iron(II) ion in $3 \cdot 2 \mathrm{MeOH}$. As a consequence of this broadening the spectra of $3 \cdot 2 \mathrm{MeOH}$ have been fit with a distribution of 20 quadrupole components, $\mathrm{i}$, with a fixed line width of $0.24 \mathrm{~mm} \mathrm{~s}^{-1}$; no correlation was found between the isomer shift and quadrupole splitting and hence a single isomer shift was used in these fits. The average quadrupole splitting, $\left\langle\Delta \mathrm{E}_{\mathrm{Q}}\right\rangle$, as well as $\sigma=$ $<\left(\Delta \mathrm{E}_{\mathrm{Q}, \mathrm{i}}-\Delta \mathrm{E}_{\mathrm{Q}}\right)^{2}>^{1 / 2}$, the square root of the variance of the distribution, are included in Table 2; the fits obtained at 225 and $4.2 \mathrm{~K}$ are shown in Fig. 6.

The temperature dependencies of the isomer shifts, $\delta$, of 1. $\mathrm{CH}_{2} \mathrm{Cl}_{2}$ and $3 \cdot 2 \mathrm{MeOH}$, see the top of $\mathrm{Fig}$. 7, are well fit with the Debye model $\underline{13}$ for the second-order Doppler shift with characteristic Mössbauer temperatures, $\Theta_{M}$, of $440(15)$ and $252(4) \mathrm{K}$, respectively. The reason for this difference is not clear at this point, but the difference is clearly a reflection of the smaller decrease in the experimental isomer shift of $\mathbf{1} \cdot \mathrm{CH}_{2} \mathrm{Cl}_{2}$ between 85 and $295 \mathrm{~K}$ than is found in $\mathbf{3} \cdot 2 \mathrm{MeOH}$.

The quadrupole splitting of $3.04 \mathrm{~mm} \mathrm{~s}^{-1}$ observed at $295 \mathrm{~K}$ for 1. $\mathrm{CH}_{2} \mathrm{Cl}_{2}$ is typical $\stackrel{12}{ }$ of that expected for iron(II) in a highly distorted pseudooctahedral coordination environment. Further, there is only a small increase of $0.24 \mathrm{~mm} \mathrm{~s}^{-1}$ in the quadrupole splitting upon cooling to $85 \mathrm{~K}$, see the centre left of Fig. 7. As is indicated by the dashed line in this figure, an attempt to fit the temperature dependence of the quadrupole splitting of $\mathbf{1} \cdot \mathrm{CH}_{2} \mathrm{Cl}_{2}$ with the Ingalls model 14 in terms of either an axial or, as shown, a rhombic crystal field splitting of the $t_{2 g}$ orbitals fails. However, a second-order polynomial fit yields $\mathrm{a}=-2.46$ $\times 10^{-6}\left(\mathrm{~mm} \mathrm{~s}^{-1}\right) / \mathrm{K}^{2}, \mathrm{~b}=-2.04 \times 10^{-4}\left(\mathrm{~mm} \mathrm{~s}^{-1}\right) / \mathrm{K}$, and $\mathrm{c}=3.31 \mathrm{~mm}$ permission has been granted for this version to appear in e-Publications@ Marquette. The Royal Society of Chemistry does not grant permission for this article to be further copied/distributed or hosted elsewhere without the express permission from the Royal Society of Chemistry. 
$\mathrm{s}^{-1}$. These parameters indicate that a lattice component, $\mathrm{q}_{\text {lat, }}$ of the electric field gradient at the iron(II) ion is most likely responsible for reducing the much larger qval valence contribution. Indeed, the Ingalls model would be expected to fail to fit the quadrupole splitting of 1. $\mathrm{CH}_{2} \mathrm{Cl}_{2}$ because the crystal field splitting is so large that there is little or no change in the Boltzmann thermal population of the higher energy orbitals upon cooling from 295 to $85 \mathrm{~K}$. In contrast, the temperature dependence of the quadrupole splitting observed for $3 \cdot 2 \mathrm{MeOH}$ is well fit with the Ingalls model, 14 see eqn (1), for a rhombic crystal field splitting of the $t_{2 g}$ orbitals and yields $\Delta_{1}=1370(10) \mathrm{cm}^{-1}$ and $\Delta_{2}=$ $570(10) \mathrm{cm}^{-1}$, values that are consistent with the symmetry of the coordination environment about the iron(II) ion in $3 \cdot 2 \mathrm{MeOH}$.

$$
\Delta E_{Q}=\Delta E_{Q, 0} \frac{\left[1+e^{-2 \Delta_{1} / k T}+e^{-2 \Delta_{2} / k T}-e^{-\Delta_{2} / k T}-e^{-\Delta_{2} / k T}-e^{-\left(\Delta_{1}+\Delta_{2}\right) / k T}\right]^{1 / 2}}{\left[1+e^{-\Delta_{1} / k T}+e^{-\Delta_{2} / k T}\right]}
$$

A fit of the temperature dependence of the logarithm of the Mössbauer spectral absorption areas with the Debye model for a solid yields Debye temperatures, $\Theta_{D}$, of $155(5)$ and $149(2) \mathrm{K}$ for $1 \cdot \mathrm{CH}_{2} \mathrm{Cl}_{2}$ and $3 \cdot 2 \mathrm{MeOH}$, respectively, see the lower portions of Fig. 7. It is well known 12 that the Mössbauer and Debye temperatures, obtained from the temperature dependencies of the isomer shifts and spectral areas, respectively, are different because they depend, for the isomer shift, on $\left\langle v^{2}\right\rangle$, the mean-square vibrational velocity of the iron-57, and, for the absorption area, on $\left\langle\mathrm{x}^{2}\right\rangle$, the mean-square displacement of the iron-57; there is no model independent relationship between these values. $\frac{13}{13}$ However, measurements of the Mössbauer temperatures on related iron(II) complexes $\frac{15,16}{}$ indicate that $\Theta_{M}$ is often at least twice as large as $\Theta_{D}$, i.e., the isomer shift is more sensitive to higher energy phonons. It appears that $\mathbf{1} \cdot \mathrm{CH}_{2} \mathrm{Cl}_{2}$ and $\mathbf{3} \cdot 2 \mathrm{MeOH}$ differ in their highenergy phonon distribution perhaps as a result of the loss of solvation molecules for $\mathbf{3} \cdot 2 \mathrm{MeOH}$.

\section{Solution Properties}

In a fashion similar to that reported previously for $\mathbf{1} \cdot \mathrm{CH}_{2} \mathrm{Cl}_{2}$, the paramagnetic NMR spectra of each complex 1-4 in methanol and their 
$295 \mathrm{~K}$ solution magnetic moments $\mu_{\mathrm{eff}} 5.2-5.6 \pm 0.3 \mu_{\mathrm{B}}$ obtained by the Evans method 17 are typical of high-spin iron(II) complexes. The colours of the complexes vary depending on the presence (or absence) and position of the methyl substituents. As solids, $\mathbf{1}$ is orange-yellow, $\mathbf{2}$ is orange, $\mathbf{3}$ and $\mathbf{4}$ are both yellow with $\mathbf{3}$ being brighter yellow as compared to 4 . The colours of methanol solutions of the complexes resemble those in the solid state giving qualitative evidence that the complexes remain intact in methanol. Quantitative evidence for solution-phase complex formation and information regarding the electronic properties of the complexes were obtained from electronic absorption spectral data by using Job's method. An overlay of the low energy portion of the UV-spectra of methanol solutions of 1-4 are provided in Fig. 8, more complete visible-NIR spectra are provided in the supporting information. \pm The spectra of $\mathbf{1 - 4}$ are comprised of four main bands. There are two higher-energy bands near $\lambda_{\max }=200(\varepsilon \sim$ $\left.10^{4} \mathrm{M}^{-1} \mathrm{~cm}^{-1}\right)$ and $\lambda_{\max }=254 \mathrm{~nm}\left(\varepsilon \sim 10^{3} \mathrm{M}^{-1} \mathrm{~cm}^{-1}\right)$, respectively, that may presumably be assigned to intra-ligand $n-\Pi^{*}$ or $n-n^{*}$ transitions or perhaps metal to ligand charge transfer, $3 d_{\mathrm{Fe}}$ to $\Pi^{*}(p y)$, transitions based on both their energies and intensities and comparisons with the spectra for the free ligands and related complexes. There is also a medium-energy, lower-intensity band near $450 \mathrm{~nm}\left(\varepsilon \sim 10^{2}-10^{3} \mathrm{M}^{-1} \mathrm{~cm}^{-1}\right.$ depending on the complex) that is tentatively assigned to a рп $(\mathrm{Cl}) \rightarrow$ Fedn ligand to metal charge transfer (LMCT) band based on a comparison with the spectrum of $\mathrm{FeCl}_{2}$ and with literature assignments for related complexes. $\underline{11}$ This LMCT band gives rise to the observed colours of the complexes and the low-energy edge of their band progressively shifts from the violet region of the electromagnetic spectrum for $\mathbf{4}$ and $\mathbf{3}$ into the lower energy (blue) region for $\mathbf{1}$ and $\mathbf{2}$. Finally, there is a very weakintensity band $\left(\varepsilon \sim 10^{0}-10^{1} \mathrm{M}^{-1} \mathrm{~cm}^{-1}\right)$, or set of split bands due to the $\mathrm{C}_{4 \mathrm{v}}$ local symmetry, found in the near-IR region for $\mathbf{1}$ and $\mathbf{2}$ with $\lambda_{\max } \sim$ $900 \mathrm{~nm}$, for 3 and 4 with $\lambda_{\max } \sim 1000 \mathrm{~nm}$, bands that are characteristic of $d-d$ transition(s) associated with high-spin iron(II) ions. An estimate of $10 \mathrm{Dq}$ for the four complexes obtained by using the average of the splitting of the $d$ - $d$ bands yields $10,400,11,000$, 9,700 , and $9,800 \mathrm{~cm}^{-1}$ for $\mathbf{1 - 4}$, respectively. These values indicate that 3-methylpyrazolyl substitution (as in the cases of $\mathbf{3}$ and $\mathbf{4}$ ) resulted in ligands with a weaker crystal field compared to those with hydrogens at the 3-position of the pyrazolyls as in the cases of $\mathbf{1}$ and permission has been granted for this version to appear in e-Publications@ Marquette. The Royal Society of Chemistry does not grant permission for this article to be further copied/distributed or hosted elsewhere without the express permission from the Royal Society of Chemistry. 
2. This observation is also in accord with the steric arguments presented above. In contrast, replacing the hydrogen with a methyl at the 4-position of a pyrazolyl as in the cases of $\mathbf{2}$ and $\mathbf{4}$ modestly increases the ligand crystal field strength in the expected manner by increasing the ligands' $\sigma$-donor abilities through inductive effects. The isomolar titration data (Job's plots, ca. $10^{-3} \mathrm{M}$ in $\underline{\mathrm{MeOH}}$, see supporting information) \pm obtained by monitoring the change in absorbance of the charge-transfer bands near 400 to $450 \mathrm{~nm}$ confirmed that complexes with $1: 1 \mathrm{FeCl}_{2}: \mathrm{pz}^{\mathrm{R}}{ }_{4}$ lut stoichiometry are formed immediately in solution.

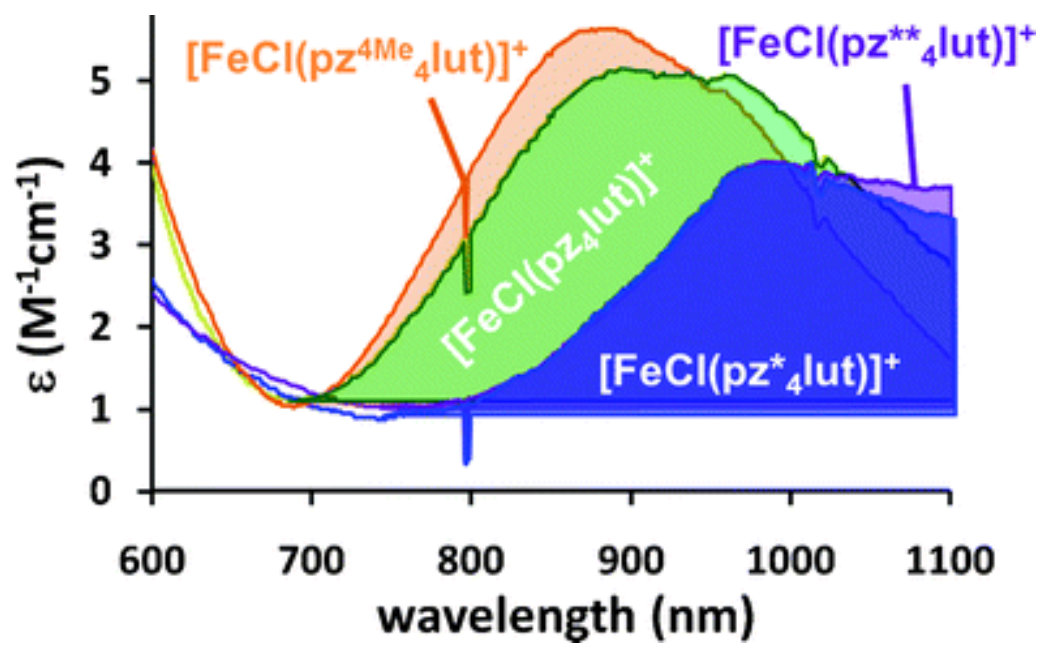

Fig. 8 Overlay of the d-d transitions in the spectra of $\mathbf{1}$, green, 2, orange, 3, blue, and 4, violet, in $\underline{\mathrm{MeOH}}$.

\section{Electrochemistry}

A comparison of the cyclic voltammograms obtained at $100 \mathrm{mV}$ $\mathrm{s}^{-1}$ of the crystalline complexes dissolved in deaerated $\mathrm{MeOH}$ with $\left(\mathrm{NBu}_{4}\right)\left(\mathrm{HSO}_{4}\right)$ as a supporting electrolyte is found in Fig. 9. Each complex exhibits an irreversible or quasi-reversible oxidation wave between ca. 0.95 to $0.75 \mathrm{~V}$ versus $\mathrm{Ag} / \mathrm{AgCl}$. Comparison of current intensities with equimolar mixtures of complexes 1-4 and ferrocene $\left(E_{1 / 2}=0.47 \mathrm{~V}\right)$ as well as spectrophotometric titrations of each complex with Magic Blue indicate the oxidation of each complex is oneelectron event. The dichotomy between complexes with methyl groups or hydrogen atoms at the 3-pyrazolyl positions persists in the electrochemical behaviour of the complexes. Complexes $\mathbf{3}$ and $\mathbf{4}$ with permission has been granted for this version to appear in e-Publications@ Marquette. The Royal Society of Chemistry does not grant permission for this article to be further copied/distributed or hosted elsewhere without the express permission from the Royal Society of Chemistry. 
3-methyl pyrazolyl substituents show lower reversibility ( $i_{p c} / i_{p a}$ ratios) than complexes $\mathbf{1}$ and $\mathbf{2}$. Although the irreversible nature of the oxidations of $\mathbf{3}$ and $\mathbf{4}$ prohibits unambiguous determination of $E_{1 / 2}$ values, the relative values of anodic potentials across the series 1-4 (or simply between $\mathbf{1}$ and $\mathbf{2}$ ) would seem to indicate that the stronger field ligands generally give less positive redox potentials, i.e., are easier to oxidize. The greater reversibility of complexes $\mathbf{1}$ and $\mathbf{2}$ relative to $\mathbf{3}$ and $\mathbf{4}$ may be indicative of the greater ability for the former versus the latter ligands in accommodating the shorter Fe-N bond distances in complexes upon oxidation of iron(II) to iron(III).

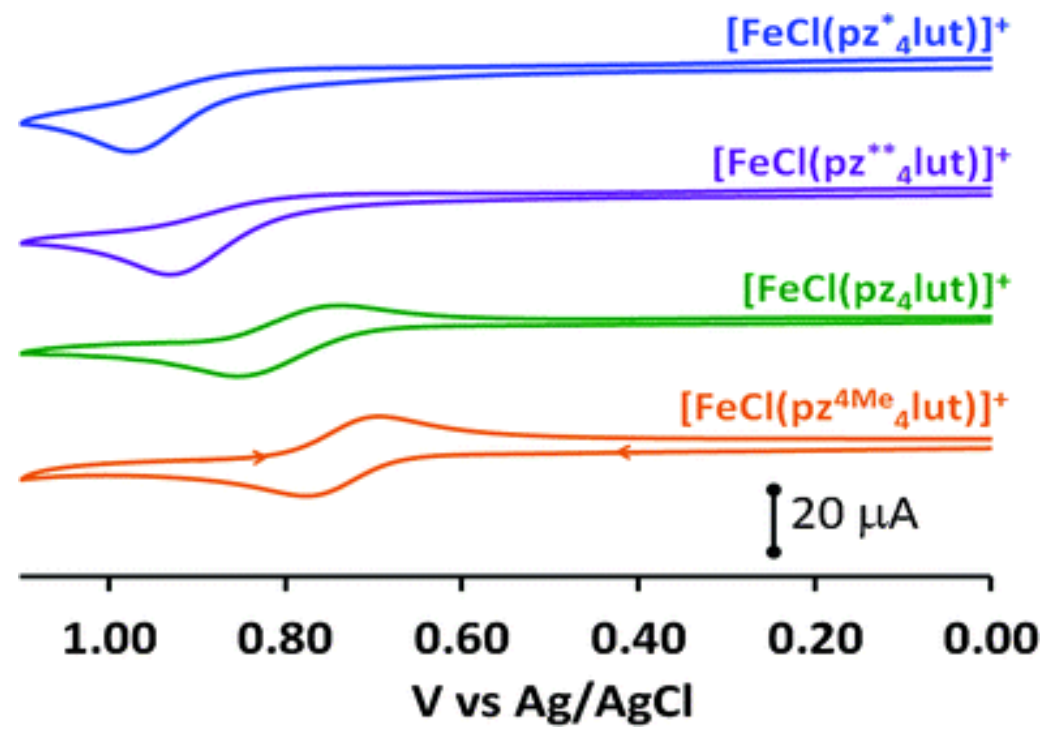

Fig. 9 Cyclic voltammograms of the iron(II) chloride complexes of $\mathrm{pz}^{\mathrm{R}} 4$ lut in MeOH obtained at $100 \mathrm{mV} \mathrm{s}^{-1}$ with $\left(\mathrm{NBu}_{4}\right)\left(\mathrm{HSO}_{4}\right)$ as the supporting electrolyte.

\section{Conclusions}

The systematic introduction of methyl groups along the pyrazolyl periphery of the tetra(pyrazolyl)lutidine ligand provides a simple means to fine-tune the apparent ligand field strength, as has been gauged by the properties of the corresponding iron(II) chloride complexes. There are small structural differences between those derivatives with and without groups at the 3-pyrazolyl position, proximal to the exogenous chloride ligand. Complexes $\mathbf{3}$ and $\mathbf{4}$, both with 3-methyl pyrazolyl substitution, show longer Fe-N bonds and greater pyrazolyl ring-twisting versus $\mathbf{1}$ and $\mathbf{2}$ without such substitution. Although the structural changes are small, they result in permission has been granted for this version to appear in e-Publications@ Marquette. The Royal Society of Chemistry does not grant permission for this article to be further copied/distributed or hosted elsewhere without the express permission from the Royal Society of Chemistry. 
modest differences in electronic properties that can be detected via examination of Mössbauer, UV-Vis-NIR spectroscopic, and electrochemical data. Derivatives with methyl groups at the 3pyrazolyl position reduce the ligand crystal field strength via intra- and inter-ligand steric interactions whereas substitution at the 4-pyrazolyl position increases ligand field strength via inductive effects. The unfavourable steric interactions are also detrimental to electrochemical reversibility.

\section{Experimental}

\section{Materials}

Pyrazole (Hpz), 4-methylpyrazole $\left(\mathrm{Hpz}^{4 \mathrm{Me}}\right)$, 3,5dimethylpyrazole ( $\left.\mathrm{Hpz}^{*}\right)$, 3-methyl-2,4-pentanedione (3Me-acacH), and $\mathrm{FeCl}_{2}$ were purchased from commercial sources and used as received. Literature procedures were used for the preparations of $\underline{2,6-}$ pyridinedicarboxaldehyde (PDCA), ${ }^{8} \mathrm{pz}^{4 \mathrm{Me}_{4}} \mathrm{lut}, \mathrm{pz}_{4}{ }_{4}$ lut, and $[\mathrm{FeCl}(\mathrm{pz}$ lut $)] \mathrm{Cl} \cdot \mathrm{CH}_{2} \mathrm{Cl}_{2}, \mathbf{1} \cdot \mathrm{CH}_{2} \mathrm{Cl}_{2} \cdot \underline{5}$ The ligand $\mathrm{pz}$ lut was prepared as previously described, but purification by column chromatography on neutral $\mathrm{Al}_{2} \mathrm{O}_{3}$ required ethyl acetate as the eluent $\left(R_{f} 0.7\right)$ rather than $\mathrm{Et}_{2} \mathrm{O}\left(\mathrm{R}_{\mathrm{f}} 0.15\right) . \underline{6}$ The synthesis of the di-methanol solvate $\left[\mathrm{FeCl}\left(\mathrm{pz}_{4}\right.\right.$ lut $\left.)\right] \mathrm{Cl} \cdot 2 \mathrm{MeOH}, \mathbf{1} \cdot 2 \mathrm{MeOH}$ is included below for comparison. Solvents were dried by conventional methods and distilled prior to use. The syntheses of the iron(II) complexes were carried out under a nitrogen atmosphere by using standard Schlenk techniques. Owing to the hygroscopic behaviour, electrochemical and spectroscopic measurements of 1-4 were made on freshly crystallized from methanol and vacuum dried samples.

\section{Instrumentation}

Midwest MicroLab, LLC, Indianapolis, Indiana 45250, performed all elemental analyses.

${ }^{1} \mathrm{H}$ and ${ }^{13} \mathrm{C}$ NMR spectra were recorded on a Varian $400 \mathrm{MHz}$ spectrometer. Chemical shifts were referenced to solvent resonances at $\delta_{\mathrm{H}} 7.26$ and $\delta_{\mathrm{C}} 77.23$ for $\mathrm{CDCl}_{3}, \delta_{\mathrm{H}} 1.96$ and $\delta_{\mathrm{C}} 118.9$ for $\mathrm{CD}_{3} \mathrm{CN}$. Absorption spectral measurements were recorded on an Agilent 8453

Dalton Transactions, Vol. 40, No. 31 (August 2011): pg. 8024-8034. DOI. This article is (c) Royal Society of Chemistry and permission has been granted for this version to appear in e-Publications@Marquette. The Royal Society of Chemistry does not grant permission for this article to be further copied/distributed or hosted elsewhere without the express permission from the Royal Society of Chemistry. 
spectrometer. Melting point determinations were made on samples contained in glass capillaries using an Electrothermal 9100 apparatus and are uncorrected.

The magnetic moments were also measured in $\mathrm{MeOH}$ solution by the Evans method. $\underline{17}$

Electrochemical measurements were collected under a nitrogen atmosphere at a scan rate of $100 \mathrm{mV} \mathrm{s}^{-1}$ for samples that were $\sim 1 \mathrm{mM}$ $\mathrm{CH}_{3} \mathrm{OH}$ solutions with $0.1 \mathrm{M} \mathrm{NBu}_{4} \mathrm{HSO}_{4}$ as the supporting electrolyte. A three-electrode cell comprised of an $\mathrm{Ag} / \mathrm{AgCl}$ electrode (separated from the reaction medium with a semipermeable polymer membrane filter), a platinum working electrode, and a glassy carbon counter electrode was used for the voltammetric measurements. In this cell, the ferrocene/ferrocenium couple had an $E_{1 / 2}$ value of $+0.47 \mathrm{~V} . \underline{18}$

X-ray powder diffraction measurements were performed with a Rigaku MiniFlex II instrument by using Cu-Ka $1.54178 \AA$ radiation.

The Mössbauer spectra of $\left[\mathrm{FeCl}\left(\mathrm{pz}_{4}\right.\right.$ lut) $] \mathrm{Cl}{ }^{\cdot} \mathrm{CH}_{2} \mathrm{Cl}_{2}, \mathbf{1} \cdot \mathrm{CH}_{2} \mathrm{Cl}_{2}$, and $\left[\mathrm{FeCl}\left(\mathrm{pz}_{4}{ }_{4}\right.\right.$ lut $\left.)\right] \mathrm{Cl} \cdot 2 \mathrm{MeOH}, \mathbf{3} \cdot 2 \mathrm{MeOH}$, have been measured between 85 and $295 \mathrm{~K}$ and between 4.2 and $295 \mathrm{~K}$, respectively, on a constantacceleration spectrometer that utilized a room temperature rhodium matrix cobalt-57 source and was calibrated at $295 \mathrm{~K}$ with a-iron powder. The spectra of $1 \cdot \mathrm{CH}_{2} \mathrm{Cl}_{2}$ and $3 \cdot 2 \mathrm{MeOH}$ have been measured on absorbers that contained 56 and $22 \mathrm{mg} \mathrm{cm}^{-2}$ of compound, respectively, that had been crushed but not ground and dispersed in boron nitride powder. The spectra of $\mathbf{1} \cdot \mathrm{CH}_{2} \mathrm{Cl}_{2}$ have been fit with a single symmetric quadrupole doublet whereas the spectra of $3 \cdot 2 \mathrm{MeOH}$ have been fit with a distribution of quadrupole doublets, see below for more details. The estimated relative errors are $\pm 0.005 \mathrm{~mm} \mathrm{~s}^{-1}$ for the isomer shifts, $\pm 0.01 \mathrm{~mm} \mathrm{~s}^{-1}$ for the quadrupole splittings and line widths, and $\pm 0.005(\% \varepsilon)\left(\mathrm{mm} \mathrm{s}^{-1}\right)$ for the spectral absorption areas. The absolute errors are approximately twice as large.

\section{3,4,5-trimethylpyrazole, $\mathrm{Hpz} * *$}

This compound was prepared by using a modification of a literature procedure. $\frac{19}{}$ A solution of $5.215 \mathrm{~g}(104.2 \mathrm{mmol}) \underline{\text { hydrazine }}$ monohydrate in $30 \mathrm{~mL} \mathrm{CH} 3 \mathrm{OH}$ was slowly added via cannula transfer

Dalton Transactions, Vol. 40, No. 31 (August 2011): pg. 8024-8034. DOI. This article is (c) Royal Society of Chemistry and permission has been granted for this version to appear in e-Publications@Marquette. The Royal Society of Chemistry does not grant permission for this article to be further copied/distributed or hosted elsewhere without the express permission from the Royal Society of Chemistry. 
to a cold solution $\left(0^{\circ} \mathrm{C}\right.$, via external ice bath) of $11.89 \mathrm{~g}(104.2 \mathrm{mmol})$ $3 \mathrm{Me}-\mathrm{acacH}$ in $60 \mathrm{~mL} \mathrm{CH}{ }_{3} \mathrm{OH}$. After $15 \mathrm{~min}$, the external ice bath was removed and the mixture was heated at reflux $1 \mathrm{~h}$. Then, solvent was removed by rotary evaporation and the resulting pale yellow solid was washed with minimal $\mathrm{Et}_{2} \mathrm{O}(10 \mathrm{~mL})$ and was recrystallized by cooling a hot hexane solution to room temperature to give $11.07 \mathrm{~g}(96 \%)$ $\mathrm{Hpz}^{* *}$ as very pale yellow crystals. Mp, $137-138^{\circ} \mathrm{C}$ (lit., $136-$ $\left.139{ }^{\circ} \mathrm{C}\right) \underline{191 \mathrm{H} \mathrm{NMR}}\left(\underline{\mathrm{CDCl}_{3}}\right): \delta 8.90($ br s, $1 \mathrm{H}, \mathrm{NH}), 2.19\left(\mathrm{~s}, 6 \mathrm{H}, \mathrm{CH}_{3}\right)$, $1.90\left(\mathrm{~s}, 3 \mathrm{H}, \mathrm{CH}_{3}\right)$.

Tetrakis(3,4,5-trimethylpyrazol-1H-yl)-a,a, $a^{\prime}, a^{\prime}-2,6-$ lutidine, $p z * *_{4}$ lut

A solution of $10.00 \mathrm{~g}$ ( $90.78 \mathrm{mmol}, 6.0$ equiv.) $\mathrm{Hpz}^{* *}$ in $100 \mathrm{~mL}$ THF was added to a suspension of $2.216 \mathrm{~g}$ (92.33 mmol, 6.1 equiv.) $\mathrm{NaH}$ in $125 \mathrm{~mL}$ THF at a rate slow enough to control hydrogen evolution. The resulting solution was stirred magnetically at room temperature for 30 min, then $3.30 \mathrm{~mL}(5.40 \mathrm{~g}, 45.4 \mathrm{mmol}, 3$ equiv.) neat thionyl chloride was slowly added by syringe (dropwise, to control the slightly exothermic reaction) immediately causing the formation of a copious colorless precipitate. After the mixture had been stirred at room temperature for $1 \mathrm{~h}, 0.613 \mathrm{~g}$ (4.72 mmol, $30 \mathrm{~mol} \%) \mathrm{CoCl}_{2}$ and 2.058 $\mathrm{g}$ (15.23 mmol, 1 equiv.) PDCA were sequentially added as solids under a nitrogen blanket. The reaction flask was fitted with a condenser and the mixture was heated at reflux $40 \mathrm{~h}$ under nitrogen. After cooling to room temperature, $50 \mathrm{~mL} \mathrm{CH}_{2} \mathrm{Cl}_{2}$ and $100 \mathrm{~mL}$ of 4 wt\% $\mathrm{NaHCO}_{3}$ and $1 \mathrm{wt} \%$ EDTA in water were added to the mixture. The layers were separated and the aqueous phase was washed with three $50 \mathrm{~mL}$ portions of $\mathrm{CH}_{2} \mathrm{Cl}_{2}$. The combined organic layers were washed with two $100 \mathrm{~mL}$ portions of water, dried over $\mathrm{MgSO}_{4}$, and filtered to give a brown oily residue after removing solvent by rotary evaporation. The residue was subjected to column chromatography on neutral alumina by using $\mathrm{Et}_{2} \mathrm{O}$ as the eluent. The second band $\left(\mathrm{R}_{\mathrm{f}} 0.76\right.$ on an $\mathrm{Al}_{2} \mathrm{O}_{3}$ plate) was collected and solvent was removed to give 5.67 $\mathrm{g}(69 \%)$ of the desired product as a colourless solid. In cases where solvent evaporation affords an oil, trituration with minimal fresh $\mathrm{Et}_{2} \mathrm{O}$ will give the compound as a powder. Mp, $169-170{ }^{\circ} \mathrm{C}$. Anal. Calcd. (obsd.) for $\mathrm{C}_{31} \mathrm{H}_{41} \mathrm{~N}_{9}$ : C, 68.99 (68.92); $\mathrm{H}, 7.66$ (7.56); N, 23.36 (23.27). ${ }^{1} \mathrm{H} \mathrm{NMR}\left(\underline{\mathrm{CDCl}_{3}}\right): \delta 7.64\left(\mathrm{t}, \mathrm{J}=8 \mathrm{~Hz}, 1 \mathrm{H}, \mathrm{H}_{4}-\mathrm{py}\right), 7.40(\mathrm{~s}, 2 \mathrm{H}$, permission has been granted for this version to appear in e-Publications@ Marquette. The Royal Society of Chemistry does not grant permission for this article to be further copied/distributed or hosted elsewhere without the express permission from the Royal Society of Chemistry. 
$\left.\mathrm{CH}(\mathrm{pz})_{2}\right), 6.98\left(\mathrm{~d}, \mathrm{~J}=8 \mathrm{~Hz}, 2 \mathrm{H}, \mathrm{H}_{3,5}-\mathrm{py}\right), 2.10\left(\mathrm{~s}, 12 \mathrm{H}, \mathrm{CH}_{3}\right), 1.96$ (s, $\left.12 \mathrm{H}, \mathrm{CH}_{3}\right), 1.84\left(\mathrm{~s}, 12 \mathrm{H}, \mathrm{CH}_{3}\right) \cdot{ }^{13} \mathrm{C} \mathrm{NMR}\left(\underline{\mathrm{CDCl}_{3}}\right): \delta 155.2,147.5$, 137.7, 137.5, 122.4, 112.7, 75.0, 12.2, 9.8, 8.2. UV-Vis $\left(\mathrm{CH}_{3} \mathrm{CN}\right) \lambda_{\max }$ $\mathrm{nm}\left(\varepsilon, \mathrm{M}^{-1} \mathrm{~cm}^{-1}\right): 227(30,400), 268(7,700)$.

A solution of $10.00 \mathrm{~g}$ ( $90.78 \mathrm{mmol}, 6.0$ equiv.) $\mathrm{Hpz}^{* *}$ in $100 \mathrm{~mL}$ THF was added to a suspension of $2.216 \mathrm{~g}$ (92.33 mmol, 6.1 equiv.) $\mathrm{NaH}$ in $125 \mathrm{~mL}$ THF at a rate slow enough to control hydrogen evolution. The resulting solution was stirred magnetically at room temperature for $30 \mathrm{~min}$, then $3.30 \mathrm{~mL}(5.40 \mathrm{~g}, 45.4 \mathrm{mmol}, 3$ equiv.) neat thionyl chloride was slowly added by syringe (dropwise, to control the slightly exothermic reaction) immediately causing the formation of a copious colorless precipitate. After the mixture had been stirred at room temperature for $1 \mathrm{~h}, 0.613 \mathrm{~g}$ (4.72 mmol, $30 \mathrm{~mol} \%) \mathrm{CoCl}_{2}$ and $2.058 \mathrm{~g}$ (15.23 mmol, 1 equiv.) PDCA were sequentially added as solids under a nitrogen blanket. The reaction flask was fitted with a condenser and the mixture was heated at reflux $40 \mathrm{~h}$ under nitrogen. After cooling to room temperature, $50 \mathrm{~mL} \mathrm{CH}_{2} \mathrm{Cl}_{2}$ and $100 \mathrm{~mL}$ of 4 wt\% $\mathrm{NaHCO}_{3}$ and $1 \mathrm{wt} \%$ EDTA in water were added to the mixture. The layers were separated and the aqueous phase was washed with three $50 \mathrm{~mL}$ portions of $\mathrm{CH}_{2} \mathrm{Cl}_{2}$. The combined organic layers were washed with two $100 \mathrm{~mL}$ portions of water, dried over $\mathrm{MgSO}_{4}$, and filtered to give a brown oily residue after removing solvent by rotary evaporation. The residue was subjected to column chromatography on neutral alumina by using $\mathrm{Et}_{2} \mathrm{O}$ as the eluent. The second band $\left(\mathrm{R}_{\mathrm{f}} 0.76\right.$ on an $\mathrm{Al}_{2} \mathrm{O}_{3}$ plate) was collected and solvent was removed to give 5.67 $\mathrm{g}(69 \%)$ of the desired product as a colourless solid. In cases where solvent evaporation affords an oil, trituration with minimal fresh $\mathrm{Et}_{2} \mathrm{O}$ will give the compound as a powder. $\mathrm{Mp}, 169-170{ }^{\circ} \mathrm{C}$. Anal. Calcd. (obsd.) for $\mathrm{C}_{31} \mathrm{H}_{41} \mathrm{~N}_{9}$ : C, 68.99 (68.92); $\mathrm{H}, 7.66$ (7.56); N, 23.36 (23.27). ${ }^{1 \mathrm{H} N M R}\left(\underline{\mathrm{CDCl}_{3}}\right): \delta 7.64\left(\mathrm{t}, \mathrm{J}=8 \mathrm{~Hz}, 1 \mathrm{H}, \mathrm{H}_{4}-\mathrm{py}\right), 7.40(\mathrm{~s}, 2 \mathrm{H}$, $\left.\mathrm{CH}(\mathrm{pz})_{2}\right), 6.98$ (d, J = $\left.8 \mathrm{~Hz}, 2 \mathrm{H}, \mathrm{H}_{3,5}-\mathrm{py}\right), 2.10\left(\mathrm{~s}, 12 \mathrm{H}, \mathrm{CH}_{3}\right), 1.96$ (s, $\left.12 \mathrm{H}, \mathrm{CH}_{3}\right), 1.84\left(\mathrm{~s}, 12 \mathrm{H}, \mathrm{CH}_{3}\right) .{ }^{13} \mathrm{C} \mathrm{NMR}\left(\underline{\mathrm{CDCl}_{3}}\right): \delta 155.2,147.5$, $137.7,137.5,122.4,112.7,75.0,12.2,9.8,8.2$. UV-Vis $\left(\mathrm{CH}_{3} \mathrm{CN}\right) \lambda_{\max }$ $\mathrm{nm}\left(\varepsilon, \mathrm{M}^{-1} \mathrm{~cm}^{-1}\right): 227(30,400), 268(7,700)$.

Dalton Transactions, Vol. 40, No. 31 (August 2011): pg. 8024-8034. DOI. This article is (c) Royal Society of Chemistry and permission has been granted for this version to appear in e-Publications@ Marquette. The Royal Society of Chemistry does not grant permission for this article to be further copied/distributed or hosted elsewhere without the express permission from the Royal Society of Chemistry. 


\section{$[\mathrm{Fe}(\mathrm{Cl})(\mathrm{pz} / \mathrm{lut})] \mathrm{Cl} \cdot 2 \mathrm{MeOH}, 1 \cdot 2 \mathrm{MeOH}$}

A solution of $0.341 \mathrm{~g}$ (2.69 mmol) $\mathrm{FeCl}_{2}$ in $20 \mathrm{~mL} \mathrm{CH} 3 \mathrm{OH}$ was transferred via cannula to a colorless solution of $1.00 \mathrm{~g}(2.69 \mathrm{mmol})$ pz 4 lut in $15 \mathrm{~mL} \mathrm{CH} 3 \mathrm{OH}$. The flask originally containing $\mathrm{FeCl}_{2}$ was washed with $15 \mathrm{~mL} \underline{\mathrm{MeOH}}$ to ensure quantitative transfer. Upon initial mixing, an orange solution had formed and after an induction period of about $1 \mathrm{~min}$, a yellow-orange solid precipitated. After the suspension had been stirred for $1 \mathrm{~h}$, the precipitate was collected by filtration, washed twice with $10 \mathrm{~mL}$ of $\mathrm{Et}_{2} \mathrm{O}$, and dried under vacuum for $14 \mathrm{~h}$ to give $1.211 \mathrm{~g}(80 \%)$ of $\mathbf{1} \cdot 2 \mathrm{MeOH}$ as a yellow microcrystalline powder. An additional $0.120 \mathrm{~g}$ was obtained by rotary evaporation of solvent from the filtrate, washing the residue with $\mathrm{Et}_{2} \mathrm{O}$, and drying under vacuum. Total $1.331 \mathrm{~g}$ ( $88 \%$ yield). Mp, > $260{ }^{\circ} \mathrm{C}$. Anal. Calcd. (obsd.) for $\mathrm{C}_{21} \mathrm{H}_{25} \mathrm{~N}_{9} \mathrm{Cl}_{2} \mathrm{FeO}_{2}$ : C, 44.86 (45.03); $\mathrm{H}, 4.48$ (4.71); N, 22.42 (22.59). $\mu_{\text {eff }}\left(E v a n s, C D_{3} \mathrm{OD}\right): 5.2 \pm 0.3 \mu_{\mathrm{B}}$ UV-Vis $\left(\mathrm{CH}_{3} \mathrm{OH}\right) \lambda_{\max }, \mathrm{nm}$ $\left(\varepsilon, \mathrm{M}^{-1} \mathrm{~cm}^{-1}\right): 210(42,400), 265$ (8,800), 298 (2,500), 448 (170), 890 (4), 960 (4). A mixture of crystals of $1 \cdot 2 \mathrm{MeOH}$ (major, prisms) and $\mathbf{1} \cdot \mathrm{MeOH}$ (minor, block) suitable for single crystal X-ray diffraction were grown by slow cooling a $60^{\circ} \mathrm{C}$ supersaturated solution to room temperature over the course of several hours. Powder X-ray diffraction indicates that the microcrystalline bulk sample from the reaction is mainly $\mathbf{1} \cdot 2 \mathrm{MeOH}$ (with a trace of $\mathbf{1} \cdot \mathrm{MeOH}$, that could arise during the experiment). A powdered sample exposed to the laboratory atmosphere for several weeks analysed as a trihydrate. Anal. Calcd. (obsd.) for $\mathrm{C}_{19} \mathrm{H}_{23} \mathrm{~N}_{9} \mathrm{Cl}_{2} \mathrm{FeO}_{3}, 1 \cdot 3 \mathrm{H}_{2} \mathrm{O}: \mathrm{C}, 41.33$ (41.53); $\mathrm{H}, 4.20$ (3.99); $\mathrm{N}, 22.83$ (22.62).

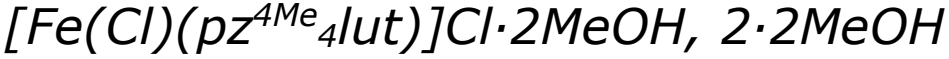

In a procedure similar to the above, a mixture of $0.290 \mathrm{~g}(0.678$

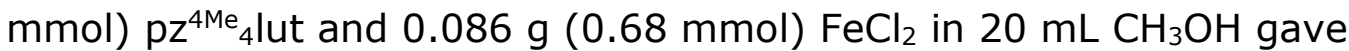
a total yield, $0.270 \mathrm{~g}, 66 \%(0.260 \mathrm{~g}$ insoluble portion and $0.010 \mathrm{~g}$ from filtrate) of $\mathbf{2} \cdot 2 \mathrm{MeOH}$ as an orange microcrystalline powder. Mp, $250{ }^{\circ} \mathrm{C}$ (decomp.). Anal. Calcd. (obsd.) for $\mathrm{C}_{25} \mathrm{H}_{33} \mathrm{~N}_{9} \mathrm{Cl}_{2} \mathrm{FeO}_{2}$ : C, 48.56 (48.88); $\mathrm{H}, 5.38$ (5.75); N, 20.39 (20.51). $\mu_{\text {eff }}$ (Evans, $\mathrm{CD}_{3} \mathrm{OD}$ ): $5.2 \pm$ $0.1 \mu_{\mathrm{B}}$. UV-Vis $\left(\mathrm{CH}_{3} \mathrm{OH}\right) \lambda_{\max }, \mathrm{nm}\left(\varepsilon, \mathrm{M}^{-1} \mathrm{~cm}^{-1}\right): 216(18,400), 271$ $(3,900), 300$ (1200), 462 (200), 874 (5), 960 (4). Slow cooling a hot supersaturated $\mathrm{MeOH}$ solution over several hours to room temperature

Dalton Transactions, Vol. 40, No. 31 (August 2011): pg. 8024-8034. DOI. This article is (c) Royal Society of Chemistry and permission has been granted for this version to appear in e-Publications@Marquette. The Royal Society of Chemistry does not grant permission for this article to be further copied/distributed or hosted elsewhere without the express permission from the Royal Society of Chemistry. 
affords very small crystals of $\mathbf{2} \cdot 2 \mathrm{MeOH}$ that were not suitable for single crystal X-ray diffraction. X-ray quality crystals of

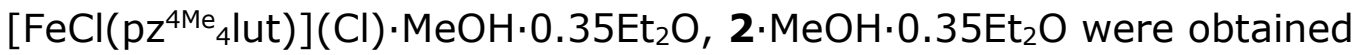
by slow evaporation of solvents from an unsuccessful attempt at crystallization by vapor diffusion of $\mathrm{Et}_{2} \mathrm{O}$ into a $\mathrm{MeOH}$ solution of the complex. A crystalline sample exposed to the laboratory atmosphere over the course of about a week analysed as the hydrate, $2 \cdot \mathrm{H}_{2} \mathrm{O}$ : Anal. Calcd (found) for $\mathrm{C}_{23} \mathrm{H}_{27} \mathrm{~N}_{9} \mathrm{Cl}_{2} \mathrm{FeO}$ : C, 48.27 (48.05); $\mathrm{H}, 4.76$ (4.47); N, 22.03 (21.71). A powdered sample exposed to the laboratory atmosphere over the course of two weeks analysed as the dihydrate, 2. $2 \mathrm{H}_{2} \mathrm{O}$. Anal. Calcd. (obsd.) for $\mathrm{C}_{23} \mathrm{H}_{29} \mathrm{~N}_{9} \mathrm{Cl}_{2} \mathrm{FeO}_{2}, \mathbf{2} \cdot 2 \mathrm{H}_{2} \mathrm{O}: \mathrm{C}, 46.80$ (47.06); H, 4.95 (4.59); N, 21.36 (20.98).

\section{$\left[\mathrm{Fe}(\mathrm{Cl})\left(\mathrm{pz}_{4}{ }_{4} \mathrm{lut}\right)\right] \mathrm{Cl} \cdot 2 \mathrm{MeOH}, 3 \cdot 2 \mathrm{MeOH}$}

Similar to the procedure above, a mixture of $0.265 \mathrm{~g}$ (2.09 $\mathrm{mmol}) \mathrm{FeCl}_{2}$ and $1.010 \mathrm{~g}$ (2.09 mmol) pz* ${ }_{4}$ lut in $60 \mathrm{~mL} \mathrm{CH} \mathrm{CH}_{3} \mathrm{OH}$ gave a total yield of $1.26 \mathrm{~g}, 89 \%$ ( $0.994 \mathrm{~g}$ insoluble portion and $0.266 \mathrm{~g}$ from filtrate) of $3 \cdot 2 \mathrm{MeOH}$ as a yellow powder. Mp, $236-250{ }^{\circ} \mathrm{C}$ (decomp.). Anal. Calcd. (obsd.) for $\mathrm{C}_{29} \mathrm{H}_{41} \mathrm{~N}_{9} \mathrm{Cl}_{2} \mathrm{FeO}_{2}$ : C, 51.64 (51.44); $\mathrm{H}, 6.13$ (6.32); N, 18.69 (18.39). $\mu_{\text {eff }}\left(\right.$ Evans, $\left.C D_{3} \mathrm{OD}\right): 5.5 \pm 0.1 \mu_{\mathrm{B}}$. UV-Vis $\left(\mathrm{CH}_{3} \mathrm{OH}\right) \lambda_{\max }, \mathrm{nm}\left(\varepsilon, \mathrm{M}^{-1} \mathrm{~cm}^{-1}\right): 228(28,000), 266(6,000), 404(60)$, 985 (3). A mixture of crystals of mainly $3 \cdot 2 \mathrm{MeOH}$ (plates) and trace amount of $\mathbf{3} \cdot \mathrm{MeOH}$ (as needles, containing $11 \%$ bromide ion impurity, likely from $\mathrm{FeCl}_{2}$ ) suitable for single crystal X-ray diffraction were grown by slow cooling a hot $\left(60^{\circ} \mathrm{C}\right)$ supersaturated solution to room temperature over the course of several hours (slow evaporation of a methanol solution can be also be used to obtain a mixture of crystals). The PXRD data indicates that the microcrystalline bulk sample from the reaction is mainly $3 \cdot 2 \mathrm{MeOH}$. A powdered sample exposed to laboratory atmosphere for several weeks analysed as a mixed solvate, 3. $2 \mathrm{H}_{2} \mathrm{O} \cdot \mathrm{MeOH}$. Anal. Calcd. (obsd.) for $\mathrm{C}_{28} \mathrm{H}_{34} \mathrm{~N}_{9} \mathrm{Cl}_{2} \mathrm{FeO}_{3}, \mathbf{3} \cdot 2 \mathrm{H}_{2} \mathrm{O} \cdot \mathrm{MeOH}$ : C, 49.57 (49.35); H, 6.09 (5.97); N, 18.58 (18.34).

Dalton Transactions, Vol. 40, No. 31 (August 2011): pg. 8024-8034. DOI. This article is (c) Royal Society of Chemistry and permission has been granted for this version to appear in e-Publications@Marquette. The Royal Society of Chemistry does not grant permission for this article to be further copied/distributed or hosted elsewhere without the express permission from the Royal Society of Chemistry. 


\section{$\left[\mathrm{Fe}(\mathrm{Cl})\left(\mathrm{pz}^{*} *_{4} \mathrm{lut}\right)\right] \mathrm{Cl} \cdot 1.75 \mathrm{MeOH}, 4 \cdot 1.75 \mathrm{MeOH}$}

In a procedure similar to the above, a mixture of $0.232 \mathrm{~g}(1.83$ mmol) $\mathrm{FeCl}_{2}$ and $0.989 \mathrm{~g}(1.83 \mathrm{mmol}) \mathrm{pz} * *_{4}$ lut in $30 \mathrm{~mL} \mathrm{CH} \mathrm{CH}_{3} \mathrm{OH}$ gave a total yield of $1.001 \mathrm{~g}(76 \%)(0.761 \mathrm{~g}$ insoluble and $0.250 \mathrm{~g}$ from filtrate) of $4 \cdot 1.75 \mathrm{MeOH}$ as a yellow powder. Mp, $236-250{ }^{\circ} \mathrm{C}$ (decomp.). Anal. Calcd. (obsd.) for $\mathrm{C}_{32.75} \mathrm{H}_{48} \mathrm{~N}_{9} \mathrm{Cl}_{2} \mathrm{FeO}_{1.75}, 4 \cdot 1.75 \mathrm{MeOH}$ : C, 54.44 (54.07); H, 6.70 (6.70); N, 17.44 (17.68). Heff (Evans, $\left.\mathrm{CD}_{3} \mathrm{OD}, 295 \mathrm{~K}\right): 5.6 \pm 0.2 \mu_{\mathrm{B}}$. UV-Vis $\left(\mathrm{CH}_{3} \mathrm{OH}\right) \lambda_{\max }, \mathrm{nm}\left(\varepsilon, \mathrm{M}^{-1} \mathrm{~cm}^{-1}\right)$ : 230 (23,000), 268 (7,000), 404 (80), 989 (3). X-ray quality crystals were obtained by cooling a supersaturated $\mathrm{MeOH}$ solution at $65^{\circ} \mathrm{C}$ to room temperature over the course of a few hours. Alternatively, slow evaporation of a methanol solution can also be used to obtain crystals. The powder X-ray diffraction pattern of the as-isolated solid from the preparative reaction matches the pattern calculated from the singlecrystal X-ray diffraction (see text and Supporting Information). A sample exposed to laboratory atmosphere over the course of a week analysed as the trihydrate, $4 \cdot 3 \mathrm{H}_{2} \mathrm{O}$ : Anal. Calcd. (obsd.) for $\mathrm{C}_{31} \mathrm{H}_{47} \mathrm{~N}_{9} \mathrm{Cl}_{2} \mathrm{FeO}_{3}, 4 \cdot 3 \mathrm{H}_{2} \mathrm{O}: \mathrm{C}, 51.68$ (51.30); $\mathrm{H}, 6.57$ (6.52); N, 17.50 (17.45).

\section{Crystallography}

While the low temperature $\left(100 \mathrm{~K}\right.$ ) crystal structure of $\mathbf{1} \cdot \mathrm{CH}_{2} \mathrm{Cl}_{2}$ has been reported previously, $\underline{5}$ the high temperature $270 \mathrm{~K}$ structure is given here for the first time. $\mathrm{X}$-ray intensity data from an orange block of $[\mathrm{FeCl}(\mathrm{pz}$ lut $)](\mathrm{Cl}) \cdot \mathrm{CH}_{2} \mathrm{Cl}_{2}, \mathbf{1} \cdot \mathrm{CH}_{2} \mathrm{Cl}_{2}$, an orange block of

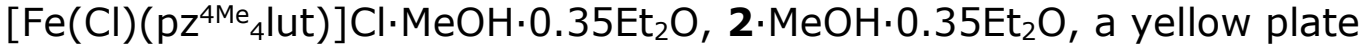
of $\left[\mathrm{Fe}(\mathrm{Cl})\left(\mathrm{pz} *{ }_{4} \mathrm{lut}\right)\right] \mathrm{Cl} \cdot 2 \mathrm{MeOH}, 3 \cdot 2 \mathrm{MeOH}$, and a yellow needle of $\left[\mathrm{FeCl}\left(\mathrm{pz}_{4}{ }_{4} \mathrm{lut}\right)\right]\left(\mathrm{Br}_{0.11} / \mathrm{Cl}_{0.89}\right) \cdot \mathrm{MeOH}, 3 \cdot \mathrm{MeOH}$, were collected at $270(2) \mathrm{K}$ for the first complex and at $100(2) \mathrm{K}$ for the remaining complexes with a Bruker AXS 3-circle diffractometer equipped with a SMART2 ${ }^{20} \mathrm{CCD}$ detector ( $\mathrm{Cu}$-Ka radiation, $\lambda=1.54178 \AA$ ). X-ray intensity data from a yellow prism of $[\mathrm{Fe}(\mathrm{Cl})(\mathrm{pz}$ lut $)] \mathrm{Cl} \cdot 2 \mathrm{MeOH}, \mathbf{1} \cdot 2 \mathrm{MeOH}$, a yellow block of $[\mathrm{Fe}(\mathrm{Cl})(\mathrm{pz}$ lut $)] \mathrm{Cl} \cdot \mathrm{MeOH}, \mathbf{1} \cdot \mathrm{MeOH}$, and a yellow needle of $\left[\mathrm{Fe}(\mathrm{Cl})\left(\mathrm{pz} * *_{4}\right.\right.$ lut $\left.)\right] \mathrm{Cl} \cdot 1.75 \mathrm{MeOH}, 4 \cdot 1.75 \mathrm{MeOH}$ were collected at $100(2)$ $\mathrm{K}$ with an Oxford Diffraction Ltd. Supernova diffractometer equipped with a $135 \mathrm{~mm}$ Atlas CCD detector, by using Cu-Ka radiation, $\lambda=$ $1.54178 \AA$ for $\mathbf{1} \cdot 2 \mathrm{MeOH}$ and Mo-Ka radiation, $\lambda=0.7107 \AA$, for the 
other two complexes. Raw data frame integration and Lp corrections were performed with SAINT+ $+\underline{20}$ for the data collected from the Bruker instrument but with CrysAlisPro $\underline{21}$ for that from the Oxford instrument. Final unit cell parameters were determined by least-squares refinement of 8435 reflections from the data set of $\mathbf{1} \cdot \mathrm{CH}_{2} \mathrm{Cl}_{2}, 5134$ reflections from the data set of $\mathbf{1} \cdot 2 \mathrm{MeOH}, 13123$ reflections from that of $\mathbf{1} \cdot \mathrm{MeOH}, 7705$ reflections from that of $\mathbf{2} \cdot \mathrm{MeOH} \cdot 0.35 \mathrm{Et}_{2} \mathrm{O}, 5682$ reflections from that of $3 \cdot 2 \mathrm{MeOH}, 2677$ reflections from that of $\mathbf{3} \cdot \mathrm{MeOH}$, and 21423 reflections from that of $\mathbf{4} \cdot 1.75 \mathrm{MeOH}$, each with I $>2 \sigma(\mathrm{I})$. Analysis of the data showed negligible crystal decay during data collection in each case. Direct methods structure solutions, difference Fourier calculations and full-matrix least-squares refinements against $\mathrm{F}^{2}$ were performed with SHELXTL. $\underline{22}$ Numerical absorption corrections based on the real shapes of the crystals for 1. $\mathrm{CH}_{2} \mathrm{Cl}_{2}, \mathbf{1} \cdot 2 \mathrm{MeOH}, \mathbf{2} \cdot \mathrm{MeOH} \cdot 0.35 \mathrm{Et}_{2} \mathrm{O}$, and 3.2MeOH were applied using $\mathrm{SADABS} \underline{20}$ whereas an empirical absorption correction using spherical harmonics as implemented in the SCALE3 ABSPACK scaling algorithm was used for $4 \cdot 1.75 \mathrm{MeOH}$. Special details regarding structure solution and refinement follow. The crystal of $\mathbf{1} \cdot \mathrm{CH}_{2} \mathrm{Cl}_{2}$ is a pseudo-orthorhombic twin consisting of two monoclinic components with beta angle close to $90^{\circ}$. The TWIN -1 $00000-100001$ instruction was used during the refinement. For $1 \cdot 2 \mathrm{MeOH}$, the hydrogen atoms were put in geometrically calculated positions with Uiso $=1.2$ Uiso/eq of an adjacent atom (1.5 Uiso/eq for methyl groups and hydroxyls) and were refined within a riding model using appropriate fixed distances to the adjacent atoms. The methyl and $\mathrm{H} 2$ hydroxyl hydrogens' positions were optimized rotationally to fit the residual electron density. Hydroxyl atom $\mathrm{H} 1$ had its $\mathrm{y}$ and $\mathrm{z}$ coordinates refined with $\mathrm{O}-\mathrm{H}$ distance constrained. The space group $\mathrm{Cmc} 2_{1}$ was chosen because the structure is non-centrosymmetric but its cations emulate a second, pseudo mirror plane (apparent space group is $\mathrm{Cmcm}$ ). This pseudo-symmetry is broken by solvent molecules. The resulting structure either represents a racemic twin (and was handled this way) or the anomalous contributions from solvate oxygens are not enough to break the apparent centrosymmetric statistics. For $\mathbf{1} \cdot 1 \mathrm{MeOH}$, the solvate $\mathrm{MeOH}$ molecule is disordered over crystallographic 2-fold axis being tilted by $\sim 41^{\circ}$ relative to it. For $2 \cdot \mathrm{MeOH} \cdot 0.35 \mathrm{Et}_{2} \mathrm{O}$, a partially populated $(\sim 70 \%)$ solvate $\mathrm{Et}_{2} \mathrm{O}$ molecule is statistically disordered over crystallographic centre of symmetry. No other geometrical restraints permission has been granted for this version to appear in e-Publications@ Marquette. The Royal Society of Chemistry does not grant permission for this article to be further copied/distributed or hosted elsewhere without the express permission from the Royal Society of Chemistry. 
were applied during data refinement. The anisotropic refinement was unstable, so the molecule was refined isotropically. For $3 \cdot 2 \mathrm{MeOH}$ two methanol molecules are disordered over crystallographic mirror planes. One is disordered completely - its $\mathrm{C}-\mathrm{O}$ bond makes an angle of $60.4^{\circ}$ with the mirror plane. Another molecule lies in the mirror plane except for the hydrogen atoms of the methyl group which are effectively disordered over two positions. In $\mathbf{3} \cdot \mathrm{MeOH}$, a chloride ion is partially and isomorphously replaced by a bromide anion (initially detected by unreasonably reduced thermal atomic parameters in a bromide-free treatment). Both ions were restrained to have the same coordinates and anisotropic thermal parameters but their partial populations were refined assuming total population equal to unity. For $4 \cdot 1.75 \mathrm{MeOH}$, the residual electron density in spacious channels occupied by solvent was modelled by a set of methanol molecules that were refined anisotropically with arbitrary population coefficients. It was not possible to localize the corresponding hydrogen atoms and an attempt to place them geometrically was unsuccessful (and gave an unstable refinement). In all other cases, non-hydrogen atoms were refined with anisotropic displacement parameters. Hydrogen atoms were placed in geometrically idealized positions and included as riding atoms. The Xray crystallographic parameters and further details of data collection and structure refinements are presented in Tables 3 and 4.

Table 3 Crystallographic data collection and structure refinement for $\mathbf{1 - 2}$

\begin{tabular}{|c|c|c|c|c|}
\hline $\begin{array}{l}\text { Complex } \\
\text { a } R_{1}=\Sigma\left\|F_{o}|-| F_{c}\right\| / \\
w_{R_{2}}=\left[\Sigma w\left(\left|F_{o}\right|\right.\right. \\
\left.\left.\left|F_{c}\right|\right)^{2} / \Sigma w\left|F_{o}\right|^{2}\right]^{1}\end{array}$ & 1. $\mathrm{CH}_{2} \mathrm{Cl}_{2}$ & 1.MeOH & $1 \cdot 2 \mathrm{MeOH}$ & $2 \cdot \mathrm{MeOH} \cdot 0.35 \mathrm{Et}_{2} \mathrm{O}$ \\
\hline Formula & $\mathrm{C}_{20} \mathrm{H}_{19} \mathrm{Cl}_{4} \mathrm{FeN} 9$ & $\mathrm{C}_{20} \mathrm{H}_{21} \mathrm{Cl}_{2} \mathrm{FeN}_{9} \mathrm{O}$ & $\mathrm{C}_{21} \mathrm{H}_{25} \mathrm{Cl}_{2} \mathrm{FeN}_{9} \mathrm{O}_{2}$ & $\mathrm{C}_{25.39} \mathrm{H}_{32.48} \mathrm{Cl}_{2} \mathrm{FeN}_{9} \mathrm{O}_{1.35}$ \\
\hline Formula weight/g mol-1 & 583.09 & 530.21 & 562.25 & 612.10 \\
\hline Crystal system & Monoclinic & Orthorhombic & Orthorhombic & Monoclinic \\
\hline Space group & $\mathrm{P} 2{ }_{1} / \mathrm{n}$ & Cmca & $\mathrm{Cmc}_{1}$ & $\mathrm{P} 2{ }_{1} / \mathrm{n}$ \\
\hline $\mathrm{T} / \mathrm{K}$ & $270(2)$ & $100(2)$ & $100(2)$ & $100(2)$ \\
\hline$a / \AA$ & $10.5496(2)$ & $21.641(4)$ & $11.8184(2)$ & $12.9870(2)$ \\
\hline$b / \AA$ & $19.4285(3)$ & $22.294(4)$ & $11.0225(2)$ & $16.2105(2)$ \\
\hline$c / \AA$ & $12.0185(2)$ & $9.5986(19)$ & $18.9571(2)$ & $14.3844(2)$ \\
\hline$a /{ }^{\circ}$ & 90.00 & 90 & 90 & 90 \\
\hline$\beta /{ }^{\circ}$ & $90.0400(10)$ & 90 & 90 & $106.2600(10)$ \\
\hline $\mathrm{Y} /{ }^{\circ}$ & 90.00 & 90 & 90 & 90 \\
\hline$V / \AA^{3}$ & $2463.35(7)$ & $4631.0(15)$ & $2469.51(6)$ & $2907.16(7)$ \\
\hline Z & 4 & 8 & 4 & 4 \\
\hline$D_{\text {calcd }} / \mathrm{g} \mathrm{cm}^{-3}$ & 1.572 & 1.521 & 1.512 & 1.399 \\
\hline$\lambda / \AA$ (Mo or $\mathrm{Cu}-\mathrm{Ka})$ & 1.54178 & 0.7107 & 1.54178 & 1.54178 \\
\hline
\end{tabular}

Dalton Transactions, Vol. 40, No. 31 (August 2011): pg. 8024-8034. DOI. This article is @ Royal Society of Chemistry and permission has been granted for this version to appear in e-Publications@Marquette. The Royal Society of Chemistry does not grant permission for this article to be further copied/distributed or hosted elsewhere without the express permission from the Royal Society of Chemistry. 
NOT THE PUBLISHED VERSION; this is the author's final, peer-reviewed manuscript. The published version may be accessed by following the link in the citation at the bottom of the page.

\begin{tabular}{|c|c|c|c|c|}
\hline Complex & $1 \cdot \mathrm{CH}_{2} \mathrm{Cl}_{2}$ & 1.MeOH & $1.2 \mathrm{MeOH}$ & $2 \cdot \mathrm{MeOH} \cdot 0.35 \mathrm{Et}_{2} \mathrm{O}$ \\
\hline$\mu / \mathrm{mm}^{-1}$ & 9.146 & 0.915 & 7.215 & 6.157 \\
\hline Abs. correction & numerical & multi-scan & numerical & numerical \\
\hline$F(000)$ & 1184 & 2176 & 1160 & 1274 \\
\hline$\theta$ range $/^{\circ}$ & 2.27 to 67.10 & 3.37 to 29.45 & 4.67 to 70.73 & 4.06 to 67.69 \\
\hline Reflections collected & 20401 & 16592 & 7450 & 24110 \\
\hline Independent reflections & $\begin{array}{l}4234 \text { ( } R_{\text {int }} \\
0.0330)\end{array}$ & $\begin{array}{l}3038 \text { ( } R_{\text {int }} \\
0.0165)\end{array}$ & $\begin{array}{l}2296\left(R_{\text {int }}\right. \\
0.0264)\end{array}$ & $5191\left(R_{\text {int }} 0.0316\right)$ \\
\hline Abs. corr. $\min / \max$ & $0.1420 / 0.2754$ & $0.85412 / 1.0$ & $0.465 / 0.837$ & $0.3875 / 0.6072$ \\
\hline Data/restraints/parameters & $4234 / 0 / 309$ & $3038 / 1 / 167$ & $2296 / 2 / 183$ & $5191 / 0 / 364$ \\
\hline Goodness-of-fit on $F^{2}$ & 0.995 & 1.096 & 1.045 & 1.006 \\
\hline $\mathrm{R}_{1}, \mathrm{WR}_{2}[\mathrm{I}>2 \sigma(\mathrm{I})]^{\underline{a}}$ & $0.0444 / 0.1224$ & $0.0234 / 0.0663$ & $0.0293 / 0.0780$ & $0.0349 / 0.0869$ \\
\hline $\mathrm{R}_{1}, \mathrm{wR}_{2}(\mathrm{all} \text { data })^{\underline{a}}$ & $0.0491 / 0.1262$ & $0.0278 / 0.0678$ & $0.0303 / 0.0783$ & $0.0406 / 0.0891$ \\
\hline Largest diff. peak/hole/e $\AA^{-3}$ & $0.562 /-0.690$ & $0.386 /-0.287$ & $1.143 /-0.384$ & $0.400 /-0.297$ \\
\hline
\end{tabular}

Table 4 Crystallographic data collection and structure refinement for 3-4

\begin{tabular}{|c|c|c|c|}
\hline $\begin{array}{l}\text { Complex } \\
\text { a } R_{1}=\Sigma\left\|F_{o}|-| F_{c}\right\| / \Sigma \mid F_{o} \\
\quad\left[\Sigma w\left(\left|F_{o}\right|-\left|F_{c}\right|\right)^{2} / \Sigma w \mid F\right.\end{array}$ & $3 \cdot \mathrm{MeOH}$ & $3 \cdot 2 \mathrm{MeOH}$ & $44 \cdot 1.75$ MeOH \\
\hline Formula & $\mathrm{C}_{28} \mathrm{H}_{37} \mathrm{Br}_{0.11} \mathrm{Cl}_{1.89} \mathrm{FeN}_{9} \mathrm{O}$ & $\mathrm{C}_{29} \mathrm{H}_{41} \mathrm{Cl}_{2} \mathrm{FeN}_{9} \mathrm{O}_{2}$ & $\mathrm{C}_{32.75} \mathrm{H}_{41} \mathrm{Cl}_{2} \mathrm{FeN}_{9} \mathrm{O}_{1.75}$ \\
\hline Formula weight/g mol-1 & 647.31 & 674.46 & 715.50 \\
\hline Crystal system & Triclinic & Orthorhombic & Triclinic \\
\hline Space group & $\mathrm{P} \overline{1}$ & Pnma & $\mathrm{P} \overline{1}$ \\
\hline $\mathrm{T} / \mathrm{K}$ & $100(2)$ & $100(2)$ & $100(2)$ \\
\hline $\mathrm{a} / \AA$ & $8.7842(2)$ & $14.3222(2)$ & $8.8463(2)$ \\
\hline $\mathrm{b} / \AA$ & $12.5916(4)$ & $12.9169(2)$ & $14.8263(3)$ \\
\hline$c / \AA$ & $13.7985(4)$ & $17.1494(2)$ & $27.2431(5)$ \\
\hline$a /{ }^{\circ}$ & $78.599(2)$ & 90 & $87.1914(15)$ \\
\hline$\beta /{ }^{\circ}$ & $84.392(2)$ & 90 & $80.8572(17)$ \\
\hline $\mathrm{Y} /{ }^{\circ}$ & $88.6900(10)$ & 90 & $87.1666(17)$ \\
\hline $\mathrm{V} / \AA^{3}$ & $1488.93(7)$ & $3172.61(8)$ & $3520.38(12)$ \\
\hline z & 2 & 4 & 4 \\
\hline$D_{\text {calcd. }} / \mathrm{g} \mathrm{cm}^{-3}$ & 1.444 & 1.412 & 1.350 \\
\hline$\lambda / \AA(\mathrm{Mo}$ or $\mathrm{Cu}-\mathrm{Ka})$ & 1.54178 & 1.54178 & 0.7107 \\
\hline$\mu / \mathrm{mm}^{-1}$ & 6.111 & 5.709 & 0.623 \\
\hline Abs. correction & numerical & numerical & multi-scan \\
\hline$F(000)$ & 676 & 1416 & 1498 \\
\hline$\theta$ range $/^{\circ}$ & 3.28 to 67.10 & 4.02 to 67.13 & 3.37 to 29.47 \\
\hline Reflections collected & 12381 & 26706 & 47502 \\
\hline Independent reflections & $4889\left(R_{\text {int }} 0.0434\right)$ & $\begin{array}{l}2919\left(R_{\text {int }}\right. \\
0.0486)\end{array}$ & $17063\left(R_{\text {int }} 0.0391\right)$ \\
\hline Abs. corr. $\min / \max$ & $0.3745 / 0.8379$ & $0.2203 / 0.6580$ & $0.7165 / 1.0$ \\
\hline Data/restraints/parameters & $4889 / 0 / 395$ & $2919 / 0 / 300$ & $17063 / 0 / 889$ \\
\hline Goodness-of-fit on $\mathrm{F}^{2}$ & 1.032 & 1.063 & 1.087 \\
\hline
\end{tabular}

Dalton Transactions, Vol. 40, No. 31 (August 2011): pg. 8024-8034. DOI. This article is @ Royal Society of Chemistry and permission has been granted for this version to appear in e-Publications@Marquette. The Royal Society of Chemistry does not grant permission for this article to be further copied/distributed or hosted elsewhere without the express permission from the Royal Society of Chemistry. 
NOT THE PUBLISHED VERSION; this is the author's final, peer-reviewed manuscript. The published version may be accessed by following the link in the citation at the bottom of the page.

\section{Complex}

$\mathrm{R}_{1}, \mathrm{wR}_{2}[\mathrm{I}>2 \sigma(\mathrm{I})]^{a}$

$\mathrm{R}_{1}, \mathrm{WR}_{2}$ (all data) ${ }^{\underline{a}}$

Largest diff. peak/hole/e $\AA^{-3}$
$3 \cdot \mathrm{MeOH}$

$0.0410 / 0.0886$

$0.0562 / 0.0930$

$0.323 /-0.317$
$3 \cdot \mathbf{2 M e O H}$

$0.0352 / 0.0775$

$0.0393 / 0.0790 \quad 0.0769 / 0.1444$

$0.504 /-0.273 \quad 1.620 /-1.008$

\section{Acknowledgements}

JRG thanks Marquette University and the NSF (CHE-0848515) for financial support. Support for EPR spectral studies (Grant NIH-RR001980) is also gratefully acknowledged (B.B).

\section{Reference}

A. Grohmann, Dalton Trans., 2010, 39, 1432 ; A. Grohmann, Adv. Inorg. Chem., 2004, 56, 179.

R. T. Jonas and T. D. P. Stack, J. Am. Chem. Soc., 1997, 119, 8566 ; C. R. Goldsmith and T. D. P. Stack, Inorg. Chem., 2006, 45, 6048 ; C. R. Goldsmith, A. P. Cole and T. D. P. Stack, J. Am. Chem. Soc., 2005, 127, 9904.

M. E. De Vries, R. M. LaCrois, G. Roelfes, H. Koijman, A. L. Spek, R. Hage and B. L. Feringa, Chem. Commun., 1997, 1549 ; G. Roelfes, V. Vrajmasu, K. Chen, R. Y. N. Ho, J.-U. Rohde, C. Zondervan, R. M. La Crois, E. P. Lutz, M. Schudde, A. L. Spek, R. Hage, B. L. Feringa, E. Munck and L. Que Jr., Inorg. Chem., 2003, 42, 2639.

E. L.-W. Wong, G.-S. Fang, C-M. Che and N. Zhu, Chem. Commun., 2005, 4578.

T. J. Morin, B. Bennett, S. V. Lindeman and J. R. Gardinier, Inorg. Chem., 2008, 47, 7468.

T. J. Morin, A. Merkel, S. V. Lindeman and J. R. Gardinier, Inorg. Chem., 2010, 49, 7992.

K. I. The' and L. K. Peterson, Can. J. Chem., 1973, 51, 422 ; K. I. The', L. K Peterson and E. Kiehlman, Can. J. Chem., 1973, 51, 2448 ; L. K.

Peterson, E. Kiehlman, A. R. Sanger and K. I. The', Can. J. Chem., $1974,52,2367$.

U. Luening, R. Baumstark, K. Peters and H. G. Von Schnering, Liebigs Ann. Chem., 1990, 1990(2), 129 ; M. W. A. Steenland, W. Lippens, G. G. Herman and A. M. Goeminne, Bull. Soc. Chim. Belg., 1993, 102, 239. G. J. Long, F. Grandjean and D. L. Reger, Spin crossover in pyrazolylborate and pyrazolylmethane complexes, Topics in Current Chemistry, 2004, 233 ; (Spin Crossover in Transition Metal Compounds I, P. Gütlich, H. A. Goodwin, ed., Springer, Heidelberg), 91-122. permission has been granted for this version to appear in e-Publications@ Marquette. The Royal Society of Chemistry does not grant permission for this article to be further copied/distributed or hosted elsewhere without the express permission from the Royal Society of Chemistry. 
Compare also to: O. Graziani, P. Hamon, J.-Y. Thepot, L. Toupet, P. A. Szilagyi, G. Molnar, A. Bousseksou, M. Tilset and J.-R. Hamon, Inorg. Chem., 2006, 45, 5661.

J. M. Smith and J. R. Long, Inorg. Chem., 2010, 49, 11223 ; B. A. Leita, S. M. Neville, G. J. Halder, B. Moubaraki, C. J. Kepert, J.-F. Létard and K. S. Murray, Inorg. Chem., 2007, 46, 8784 ; J. M. Holland, J. A. McAllister, C. A. Kilner, M. Thornton-Pett, A. J. Bridgeman and M. A. Halcrow, J. Chem. Soc., Dalton Trans., 2002, 548 ; A. L. Thompson, A. E. Goeta, J. A. Real, A. Galet and M. C. Muñoz, Chem. Commun., 2004, 1390 ; P. Manikandan, K. Padmakumar, K. R. J. Thomas, B. Varghese, H. Onodera and P. T. Manoharan, Inorg. Chem., 2001, 40, 6930.

B. F. Little and G. J. Long, Inorg. Chem., 1978, 17, 3401 ; W. M. Reiff, G. J. Long, in Mössbauer Spectroscopy Applied to Inorganic Chemistry, G. J., Long, Ed., Volume 1, Plenum Press, New York, 1984, p. 245-285.

G. K. Shenoy, F. E. Wagner, G. M. Kalvius, in Mössbauer Isomer Shifts, G. K. Shenoy, F. E. Wagner, ed., North-Holland, Amsterdam, 1978, p. 49.

R. Ingalls, Phys. Rev., 1964, A133, 787.

D. L. Reger, J. D. Elgin, M. D. Smith, F. Grandjean, L. Rebbouh and G. J. Long, Polyhedron, 2006, 25, 2616.

D. L. Reger, J. R. Gardinier, J. D. Elgin, M. D. Smith, D. Hautot, G. J. Long and F. Grandjean, Inorg. Chem., 2006, 45, 8862 ; D. L. Reger, J. R. Gardinier, S. Bakbak, W. Gemmill, M. D. Smith, L. Rebbouh, F. Grandjean, A. M. Shahin and G. J. Long, J. Am. Chem. Soc., 2005, 127, 2303 ; D. L. Reger, J. R. Gardinier, M. D. Smith, A. M. Shahin, G. J. Long, L. Rebbouh and F. Grandjean, Inorg. Chem., 2005, 44, 1852.

D. F. Evans, J. Chem. Soc., 1959, 2003 ; D. F. Evans, G. V. Fazakerley and R. F. Phillips, J. Chem. Soc. A, 1971, 1931.

I. Noviandri, K. N. Brown, D. S. Fleming, P. T. Gulyas, P. A. Lay, A. F. Masters and L. Phillips, J. Phys. Chem. B, 1999, 103, 6713.

X. Chen, J. She, Z.-C. Shang, J. Wu and P. Zhang, Synth. Commun., 2009, 39, 947 ; D. Chambers, W. A. Denny, J. S. Buckleton and G. R. Clark, J. Org. Chem., 1985, 50, 4736.

SMART APEX2 Version 2.1-4, SAINT+ Version 7.23a and SADABS Version 2004/1. Bruker Analytical Xray Systems, Inc., Madison, Wisconsin, USA, 2005.

Oxford Diffraction (2009). CrysAlisPro. Version 1.171.33.55 Oxford Diffraction Ltd, Yarnton, Oxfordshire, England.

G. M. Sheldrick, SHELXTL Version 6.12; Bruker Analytical X-ray Systems, Inc., Madison Wisconsin, USA, 2001. 
NOT THE PUBLISHED VERSION; this is the author's final, peer-reviewed manuscript. The published version may be accessed by following the link in the citation at the bottom of the page.

\section{Footnote}

+ Electronic supplementary information (ESI) available: Additional structural information (Figures, PXRD data), electronic and EPR spectra. CCDC $\underline{825572}$ and $821757-821762$ contain the supplementary crystallographic data for various solvates of 1-4. For ESI and crystallographic data in CIF or other electronic format see DOI: $10.1039 / \mathrm{c} 1 \mathrm{dt} 10712 \mathrm{~g}$

Dalton Transactions, Vol. 40, No. 31 (August 2011): pg. 8024-8034. DOI. This article is @ Royal Society of Chemistry and permission has been granted for this version to appear in e-Publications@Marquette. The Royal Society of Chemistry does not grant permission for this article to be further copied/distributed or hosted elsewhere without the express permission from the Royal Society of Chemistry. 